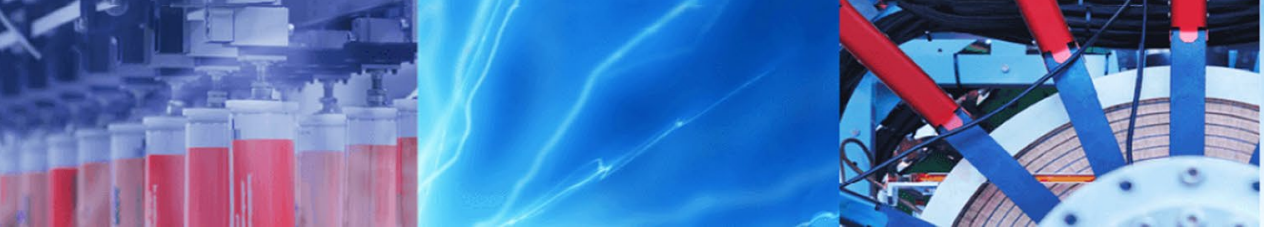

Research Article

\title{
Assessing land use land cover dynamics of wetland ecosystems using Landsat satellite data
}

\author{
Saleha Jamal ${ }^{1} \cdot$ Wani Suhail Ahmad ${ }^{1}$ (D)
}

Received: 6 August 2020 / Accepted: 13 October 2020 / Published online: 26 October 2020

(c) Springer Nature Switzerland AG 2020

\begin{abstract}
In the light of growing debates over climate change, population growth, and associated activities, wetland ecosystems have gained immeasurable importance as they have potential to serve both environmentally and economically. Hence, the evaluation of wetland ecosystems dynamics and development of comprehensive management policies demand accurate assessment of land use-land cover changes over time and distinct hydrological processes taking place in such aquatic ecosystems. Assessment of such changes is imperative to deal with various perspectives of resource management, ecosystem conservation, sustainable development and land use planning, etc. The present study aims to examine the spatiotemporal dynamics of LULC in wetland ecosystems of Kashmir Valley using Landsat datasets of the period 1994-2018. Maximum likelihood classifier was used to quantify LULC changes in ERDAS IMAGINE (14). A total of seven categories were classified viz. forest, plantation, marshy land, water body, horticulture, agriculture, and built-up. From the present analysis, two patterns of LULC changes were observed in the study area (in both cases: Wular, as well as, Hokersar and Anchar): (1) Continuous increase in area of respective categories: agriculture, horticulture, and built-up (Wular Lake); forest, plantation, agriculture, and built-up (Hokersar and Anchar Lake); (2) a consistent decrease in categories like: forest, plantation, water body, and marshy land (Wular Lake); water body, marshy land, agriculture (Hokersar and Anchar Lake). Most significant change in terms of area has been observed in plantation $-5378.18 \mathrm{ha}$, water body $-3954.94 \mathrm{ha}$, and built-up +2556.18 (Wular Lake); horticulture +4884.3 ha, built-up +6071.96 ha, agriculture $-11,605.43$ ha, and water body -106.01 ha (Hokersar and Anchar Lake). The LULC transformation, mostly driven by human-induced factors, pose a severe threat to wetland ecosystems of Kashmir Valley. Anthropogenic activities threatening the wetland ecosystems may include urban development, agriculture and horticulture practices, impacts of insecticides and pesticides, fertilizers, climate change and invasion of alien species.
\end{abstract}

Keywords Wetland ecosystem · Kashmir valley $\cdot$ Land transformation $\cdot$ Land use/land cover

\section{Introduction}

In land change sciences, land use and land cover (hereafter LULC) are two exchangeable terminologies used with different references, but often being used interchangeably [11]. The LULC pattern of any geographical area/setting is the interplay of environmental, institutional, and socioeconomic factors [35] and their exploitation by humans over space and time. Land cover represents physical characteristics covering the earth's surface, like, vegetation, soil, water and artificial constructions, while as land use refers to those activities of man in which land resources are put to use with the sole aim of obtaining products or benefits. Complex interactions between behavioral and structural factors associated with social relations, demand, infrastructural and technological capacity, lead to land-use

$\triangle$ Wani Suhail Ahmad, wanisuhailgeo@gmail.com; Saleha Jamal, salehajm@gmail.com | Department of Geography, Aligarh Muslim University, Aligarh, India.

SN Applied Sciences (2020) 2:1891 | https://doi.org/10.1007/s42452-020-03685-z 
changes affecting not only demand and function of the environment but also nature of the environment $[64,68]$. LULC changes in last few decades induced by human activities are found to be a prominent cause for degradation of the environs. These modifications in LULC have a significant impact on the physical environment of a place and also in transforming the social and economic conditions of people inhabiting that place [74]. The rate and dimensions of alterations to land surfaces by humans particularly in terms of LULC change are so encroaching and unprecedented that they eminently affect the significant features of earth systems by transforming the geography of a large part of the land surface [15, 34]. The assessment of LULC change has become essential to varied aspects of natural environment and man, and a complex interplay among them $[24,29,38]$. Ecologists throughout the world pay significant interest to adverse impacts of changing land use, especially with special concerns to aquatic ecosystems and biodiversity [66]. Changing LULC patterns in watershed of Wular Lake influence its water quality which in turn affect the biotic setup of the ecosystem. To overcome the burning issues of environmental crisis like the destruction of wetlands, loss of fertile agricultural lands, destruction of wild life habitats, unregulated development practices, it is thus imperative to evaluate the LULC changes at a regional level in particular and global level in general [4]. Hence, it is highly required to have information on LULC because this understanding is necessary for its optimal use, for better understanding of landscape dynamics, and improved decision-making, implementation and sustainable management of schemes related to land use $[41,60]$, so that the basic human needs are satisfied without jeopardizing the status of environment.

Change detection analysis is the measure of thematic change information and distinct data framework that can lead to real judgments in underlying practices in fostering LULC changes [1]. LULC change detection process involves multi-temporal information obtained through remote sensing in identifying the historical changes quantitatively in state of any phenomena or objects under investigation by observing it at different periods of time and thus helps to quantify the changes associated with LULC $[46,73]$. The study of LULC changes shows where the change is taking place, which category is changing, the type of transformation occurring, rate of change, and causes and driving forces behind the changes [40]. It also helps to understand and predict the future pattern of change through simulation modeling by depicting when, where, and why changes in LULC occur. These models of future projection use historical pattern of evolution by involving empirically fitting evaluation systems [7]. During the past five decades, remote sensing techniques have emerged as an essential tool in mapping, assessing, and monitoring spatial information about natural resources, including aquatic ecosystems. Different sensors in remote sensing capture abundant information and have been used in a number of wetland researches by scientists interested in monitoring spatial information in a timely manner [50]. Data acquired from Lidar, Radar, hyperspectral images, high-resolution images, medium-resolution images, coarse-resolution images, and aerial photographs have been used to study dynamics of wetland ecosystems using different techniques and is an emerging tool for systematic study of wetlands.

Remote sensing technology is widely used by scientists in wetland research to determine LULC changes, wetland mapping $[21,59,69]$, monitoring climate warming in wetland environs and carbon cycle $[22,25]$ and release of carbon from peatland fires [55,67], and hydrological processes in wetlands $[37,63]$. Monitoring of various landscapes through the application of remote sensing and GIS provide vital information in bringing out the results of land-use change and future planning strategies. Over the years, remote sensing satellite data in combination with descriptive models have effectively performed the assessment of LULC and offered a broad scope to obtain LULC patterns of past, present, and future $[36,44]$ in cost- and time-effective manner [14, 61, 71]. Various modeling tools are used by scientists to assess the LULC dynamics such as, GEOMOD, Markov chain, Markov, and Cellular Automata, etc. [27], but while comparing the performance, most of the models are found to be fundamentally different. Lidar data with optical images is considered as the most important tool, with high level of wetland classification accuracy by providing elevation information to derive 3-D maps of ground surface such as, water level. Its penetration capability has been widely used where optical sensors are not found feasible. Such data has been efficiently used by researchers to identify and map the extent of flood and flood affected vegetation. Similarly, high-spatial-resolution images are useful for wetland classification and species identification particularly for research pertaining to mangrove forests with potential to improve the classification accuracy of the data set under investigation. But due to high cost of these datasets, they are mostly used by researchers for small areas. Coarse resolution data of AVHRR and MODIS with low spatial resolution but large area coverage are being used to study wetlands. Indices of MODIS and AVHRR such as NDPI, NDMI, NDWI, and NDVI are considered useful for wetland studies. Among all the datasets, aerial photographs are a type of high-resolution data employed for wetland species identification, wetland classification, wetland mapping and to test the accuracy of raster layers.

Remotely sensed data help to identify and study various features of wetlands like lagoons, salt pans, salt marshes, 
marshy vegetation, and tidal flats. In addition to these features, it helps to study the identification and monitoring of the vegetative cover, its aerial extent [49], significance, and spatiotemporal patterns $[6,54]$. Imagery using multitemporal satellite data has proved to be a commonly used tool to detect changes in wetland ecosystems since the early 1980 s [45]. According to studies, about $84 \%$ wetlands of international importance listed in Ramsar were threatened or have undergone ecological change [43], and $50 \%$ of the existing wetlands since 1990 have been lost [13]. Over the past five decades, changing land cover has resulted in pollution, degradation, and dramatical decline of wetland ecosystems in some regions of the world [23]. Wetland ecosystems have witnessed drastic permanent and seasonal alterations in response to changing LULC [33], climate change [12], water table fluctuations [17], urban expansion [20,53], and other anthropogenic activities. Changing LULC patterns result in marked spatial heterogeneity both in the structure and functioning of the wetland ecosystems. These human-induced LULC changes often generate effects hampering the ecosystems' functioning.

The Valley of Kashmir has also drastically witnessed LULC changes over the last five decades on account of numerous anthropogenic activities. The dire land transformation in the ecologically sensitive Kashmir valley, largely driven by human-induced factors has given enough scope to multiple environmental issues [2]. Among them, the most prominent causes are rapid growth rate of population, changes in agricultural practices (cost-benefit analysis), increasing urbanization, deforestation, economic growth, and implementation of developmental projects and many more, particularly during last 30 years. Water bodies of Kashmir Valley are in continuous process of eutrophication [31, 32], enhanced by unplanned urbanization, LULC changes, the in-flow of fertilizers, pesticides, insecticides from nearby agricultural and horticultural fields, and increased sedimentation from the catchment $[5,48]$. These modifications in LULC are identified as dominant factors for wetland degradation in Kashmir Himalayas [3]. However, wetlands of Indian Himalayas (of which Kashmir Himalayas are a part) are facing the crisis of inadequate information regarding their spatial extent and how they have been varying over time [19]. Uncontrolled and unregulated anthropogenic activities at an unprecedented rate in the catchment of various wetlands of Kashmir Valley like that of Wular Lake have resulted in significant negative changes in its landscape [18]. These landscape changes in and around wetland ecosystems of the Valley are still not systematically monitored, and magnitude estimations of these LULC changes are rarely being taken up. In the present study, we attempt to map and quantify the spatiotemporal LULC changes of the area, in and around the wetland ecosystems of Kashmir Valley with a buffer of 5 Sq. Km, by making use of remote sensing techniques in combination with Geographical Information System (GIS) through Landsat images of the years 1994, 2002, 2010, and 2018 , by applying change detection algorithm.

\section{Study area}

Geographically Kashmir Valley is a northwest-southeastoriented, elongated trough located within geographical coordinates of $33^{\circ} 20^{\prime}$ to $34^{\circ} 43^{\prime} \mathrm{N}$ latitudes and $73^{\circ} 52^{\prime}$ to $75^{\circ} 42^{\prime} \mathrm{E}$ longitudes in a transition zone between the mountainous region of mighty Himalayas and the IndoGangetic plains covering an area of 15,948 sq. Km. (Fig. 1), owing its origin to the tectonic movement of the local basement along the fault (Ahmad et al. 2015). This halfclosed ecosystem falling in the UTM zone $43 \mathrm{~N}$ is undeniably a gift of the Jhelum River System, made up of detritus lain down by its numerous tributaries brought down from the high mountainous areas surrounding it on all four sides. Kashmir valley finds no match in the entire Himalayan region in terms of its riches in water resources supplemented by a great diversity of freshwater bodies including lakes, ponds, wetlands, rivers and streams which assume myriad importance in sustaining its rich biodiversity, maintenance of hydrological regimes and ecological balance. Among all these water bodies, Wular and Hokersar assume weighted significance and international importance and are recognized by Ramsar Convention. Similarly, Anchar a mono-basined lake located nearly $25 \mathrm{~km}$ northwest of the Srinagar city plays an essential role in conservation and regeneration of biological diversity besides water supply, irrigation, transportation, wildlife and fishery. Though, ecologically vital for wetland biodiversity, this aquatic system has become a target of cultural eutrophication due to human stressors [39, 56]. Wular Lake, Hokersar, and Anchar Lake form the actual area of interest for the present study, hosting notable human population with their varied socioeconomic activities within these fragile ecosystems. The widespread anthropogenic interferences and changing LULC patterns in and around the wetland ecosystems of Kashmir Valley have been the motivation behind the selection of this region for investigation.

\section{Data and methodology}

\subsection{Data}

Satellite data serve as the primary source of information for LULC change detection of any geographical area over a period of time. For studying and quantifying LULC 
Fig. 1 Location of the Study area (STRM DEM): Kashmir Valley

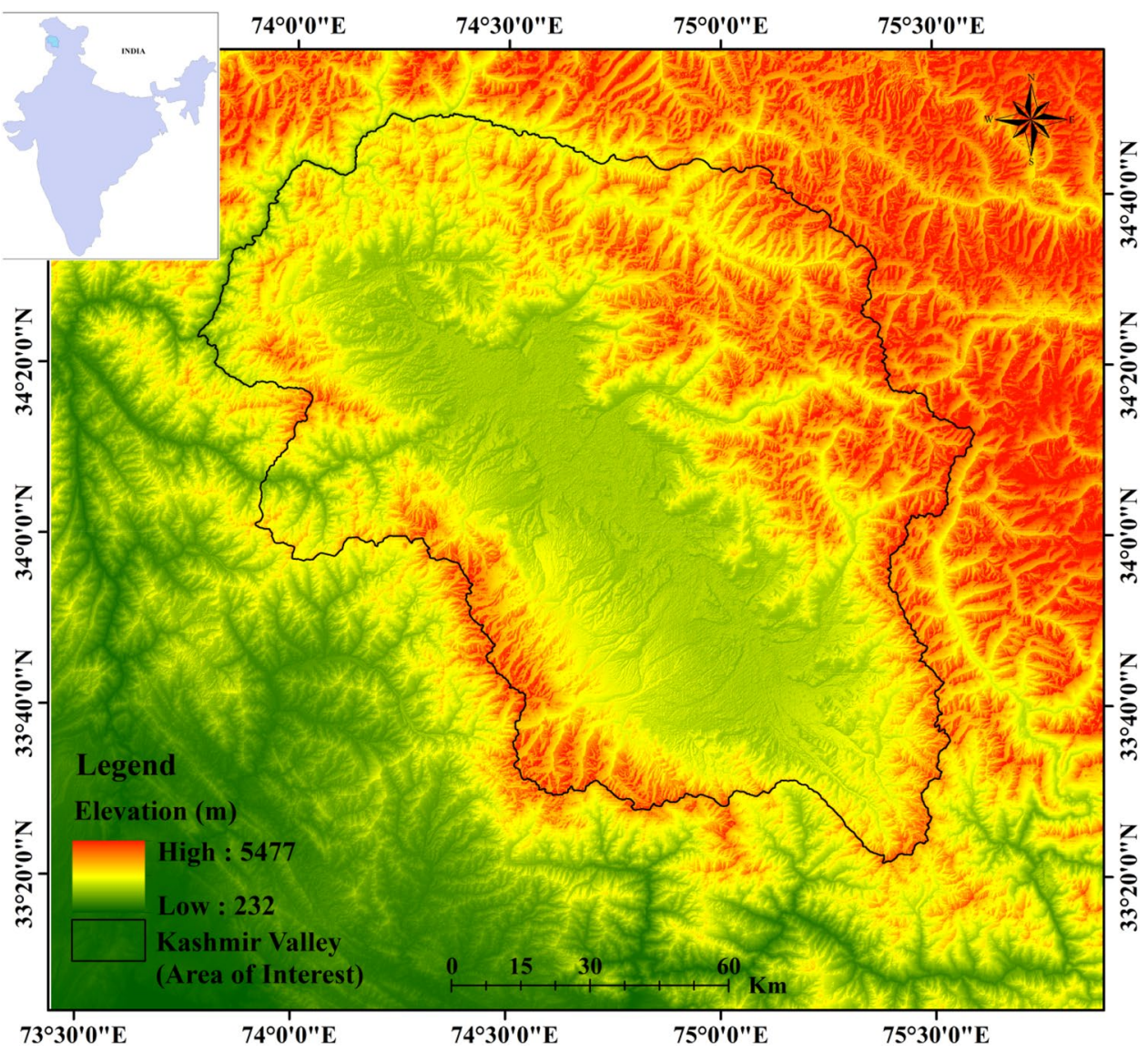

changes remote sensing approach usually involves the usage of satellite images of two or multiple dates (at least two multispectral satellite images are required for comparison). Cost-efficiency and availability of appropriate information with spatial resolution of $30 \mathrm{~m}$ compatibility providing wide range of applications [57] have been the motivation behind the selection of Landsat imagery. For analysis of LULC change in wetland ecosystems in Kashmir Valley (AOI), Landsat-5 Thematic Mapper (7 November 1994), Landsat-7 Enhanced Thematic Mapper Plus (22 September 2002 and 30 September 2010) and Landsat-8 Operational Land Imager (19tSeptember 2018) cloud-free satellite images were acquired from United States Geological Survey (USGS) (https://glovis.usgs.gov). Being already pre-processed, no atmospheric or radiometric corrections were applied to the images. However, for removal of geometric incongruity, all the images of Landsat-5 TM, Landsat-7 ETM+, and Landsat-8 OLI were co-registered to sub-pixel accuracy in ERDAS IMAGINE (14). The images for this study were selected based on season. To minimize the impacts of the changing season, images from autumn season were preferred, keeping in view the vegetative characteristics of the area, so that better results could be achieved. Specifications of the satellite data acquired for analysis of landscape dynamics are given in Table 1.

\subsection{Land use and land cover classification}

Accurate information on LULC change derived from multiband raster satellite image, used for the monitoring of

Table 1 Spatial data used in the present work

\begin{tabular}{llllc}
\hline & Data type & Source & Data specifications & Time Period \\
\hline LANDSAT-5 TM & Spatial & USGS & (30 m resolution) Path/Raw 149/36 & 7 November 1994 \\
LANDSAT-7 ETM + & Spatial & USGS & (30 m resolution) Path/Raw 149/36 & 22 September 2002 \\
& & & & and 30th September \\
& & & (PAN 15 m, 30 m resolution) Path/Raw 149/36 & 19 September 2018 \\
LANDSAT-8 OLI & Spatial & USGS & (2010
\end{tabular}


environmental change, land management, and urbanization [65] can be acquired through the process of image interpretation and classification [36]. However, in wetland ecosystems, such studies are often a challenging task, due to complications caused by mixed pixels and extremely heterogeneous landscape. To deal with such issues both parametric and nonparametric methods can be put to practice. For image classification process, nonparametric methods have shown high accuracy rates. Thus, in the present study, rule-based maximum likelihood classification (MLC) algorithm was adopted $[26,28,51,72]$ using ERDAS IMAGINE (14) software. A total of seven LULC (for details see Table 2) classes were identified in accordance with the scheme proposed by Anderson [4]. Nearly 100 to 150 training samples were collected for each category of LULC and were submitted for statistical analysis of resemblances [70]. For further enhancement of LULC classification, Google Earth and GPS (Global positioning system) facilitated/ equipped field visits were performed for ground-truthing of doubtful areas. Further, before the analysis of multi-temporal raster layers, a $3 \times 3$ majority filter to reduce the potential salt-and-pepper effect was applied [8]. Finally, multi-temporal (1994, 2002, 2010, and 2018) LULC maps were generated and for estimation of LULC change their corresponding statistics were compared. The rate of change for different LULC classes of the study area was obtained by using the following equation [52]:

$R=\left[\frac{1}{t_{1}-t_{2}}\right] \times\left[\ln \left(\frac{C_{1}}{C_{2}}\right)\right]$

where $R=$ rate of LULC change; $C_{1}$ and $C_{2}=$ area under different LU categories; $t_{1}$ and $t_{2}=$ time series 1 and 2 , respectively.

\subsection{Accuracy assessment}

Image heterogeneity and uneven distribution of data often induce some errors in LULC classification because many pixels in maximum likelihood classification remain unclassified. Thus, for accuracy assessment, the classified maps need to be put to test using reliable statistical techniques [47]. Accuracy assessment aims to measure the precision or effectiveness of pixel sampling in a classified LULC map, assessed, and quantified by error matrix [16]. Stratified random sampling technique [62] was adopted to collect 100 sample points from each category in every classified map. In this way 700 sampling points were generated in each classified map to check the classification accuracy. The number of sample points plays a vital role in determining the accuracy of classification [10]. These sample points were then selected through ground-truthing for Landsat-8 OLI image $(30 \mathrm{~m} / 2018)$, while as sample points for Landsat-5 TM (30 m/1994) and Landsat-7 ETM+ (30 m/2002 and 2010) were taken from SOI map and Google Earth Historical Imagery. Some values were neglected which depicted ' 0 ' class value. The data obtained was quantified and summarized with the help of error matrix. Thus, with the advent of error matrix necessary elements of accuracy assessment like user accuracy (errors of commission), producer accuracy (errors of omission), overall accuracy and kappa index can be obtained [42]. KAPPA coefficient $(k)$ is a robust multivariate technique and is extensively used to assess inter-rater arrangement between categorical variables [9], it takes into account all elements in the confusion matrix and not only the diagonal elements [58]. Accuracy assessment of all LULC maps generated (1994, 2002, 2010 and 2018) was carried out through the development of error-matrix. For Wular Lake, the maps generated for time periods 1994, 2002, 2010 and 2018 depict an overall accuracy of $90.85 \%, 92.57 \%, 92.28 \%, 94.42 \%$ and kappa coefficient of $0.89,0.91,0.91$ and 0.93 , respectively. Similarly, for Hokersar and Anchar Lake combined maps were generated for the time periods 1994, 2002, 2010 and 2018,

Table 2 LULC classification scheme

\begin{tabular}{|c|c|c|}
\hline S. No & Class name & Description \\
\hline 1 & Water body & Open waters, rivers, lakes, ponds, and streams for part of this category \\
\hline 2 & Marsh & $\begin{array}{l}\text { Wetlands, permanent and seasonal aquatic vegetation, sag ponds, and other naturally saturated land area } \\
\text { are included in this category }\end{array}$ \\
\hline 3 & Agriculture & Paddy, mustard, wheat, maize, vegetables, pulses, and fodder are dominated by this category \\
\hline 4 & Horticulture & Land devoted to apple, pear, peach, almond, walnut, peach, cherry, and apricots are included in this category \\
\hline 5 & Built-up & $\begin{array}{l}\text { Roads, residential area, commercial structures, industrial establishments, paved surfaces and other infrastruc- } \\
\text { ture are included in this class }\end{array}$ \\
\hline 6 & Forest & This category represents cedar, deodar, fir, blue-pine and spruce trees in mountainous areas \\
\hline 7 & Plantation & This category corresponds to social forestries like willow, poplar, elm, nettle, mesquite and mulberry trees \\
\hline
\end{tabular}


revealing an overall accuracy of $91.42 \%, 93.14 \%, 91.42 \%$ and $94.28 \%$, and kappa coefficient of $0.9,0.92,0.9$ and 0.93 , respectively (for details see Tables 3 and 4). Thus, in general, the accuracy of all the classified maps of the study area is acceptable [4], and the results of LULC obtained can be considered reliable. The maximum accuracy among all the raster layers was shown by Landsat-8 OLI (2018) image, which means that accuracy is dependent on the version of dataset. Kappa coefficient and overall accuracy of raster layers of the study area was determined by using statistical Eqs. (1) and (2)

Overall accuracy $=\sum_{i=1}^{r} x_{i i}$

where $x_{i i}=$ diagonal elements in the error matrix; $x=$ total number of samples in the error matrix

Kappa coefficient $\hat{K}=\frac{n \sum_{i=1}^{r} x_{i i}-\sum_{i=1}^{r}\left(x_{i}+x_{+i}\right)}{n^{2}-\sum_{i=1}^{r}\left(x_{i+} x_{+i}\right)}$

where $r=$ number of rows in the matrix; $x_{i i}=$ number of observations in row $i$ and column $i . x_{i+}$ and $x_{+i}=$ marginal totals of row $i$ and column $i$ respectively and $n=$ total number of observations (samples/pixels).

\section{Results and discussion}

Wetland ecosystems of the Kashmir valley have observed considerable LULC changes throughout their length and breadth during last three decades. The description of LULC of the various classified categories of the study area (1994-2002-2010-2018) including a buffer of 5 Sq. Km. in wetland ecosystems of Wular Lake (separately), and Hokersar and Anchar Lake (combined) are illustrated in Figs. 2, $3 a, b, 4,5 a, b$ and Tables 5 and 6 , respectively.

\subsection{Dynamics of LULC in the study area}

LULC of Wular Lake.

\subsubsection{Agriculture}

Among all the classified categories of LULC in the study area, agriculture has the maximum share throughout all time periods considered in the study. The total area under agriculture has been found to be $14,591.30$ ha in the year $1994,16,291.10$ ha in $2002,17,463.10$ ha in 2010 and $18,409.83$ in 2018 (Figs. 2, 3a, Table 5). The analysis of the Landsat-5 TM image reveals that there has been a continuous increase of agricultural land throughout the study area and time period with a net increase of 3818.53 ha from
1994 to 2018 . The maximum growth of about 1700 ha has been recorded from 1994 to 2002. The main reason for this increase is associated with encroachment, where vast chunks of the land have been reclaimed for the cultivation of paddy around the Wular Lake. In addition to this, the continuous deposition of fresh alluvium by river Jhelum, Madumati, Irin and other rivers and streams, during excessive rain, floods and throughout the year due to water availability, which form prerequisite conditions for the cultivation of paddy are the driving forces for the increase of agriculture land around the Wular Lake.

\subsubsection{Forest}

Forest cover in the study area was found to occupy an area of 2952.45 ha in the year 1994, 2866.71 ha in 2002, 2759.38 ha in 2010 and 2501.60 ha in 2018 , thus revealing a continuous pattern of decrease in its share in all the time periods, registering a net loss of -450.85 ha from 1994 to 2018 (Figs. 2, 3b; Table 5). One of the main reasons to have fostered this decrease in forest category is the political turmoil and consequent disturbance in the valley after early 1990s during which many people took advantage of the dismal law and order situation enabling them to extract resources more unabatedly (https://kashmirlife.net/strai ning-forests-issue-31-vol-07-87503/), which is clearly visible in the form of increasing deforestation, encroachment, overgrazing leading to the problems of soil erosion, and landslides.

\subsubsection{Built-up}

Built-up area of is found to be one among the various noticeable (comparatively) categories of LULC in Wular Lake ( $5 \mathrm{Sq}$. km buffer). This category reveals a continuous increase constituting 77.31 ha, 603.22 ha, 1288.56 ha, and 2633.49 ha in the years 1994, 2002, 2010 and 2018, respectively, registering a tremendous net growth rate of 3306.37\% from 1994 to 2018 (Figs. 2, 6, 7; Table 5), owing to the growth in population, increase in the number of houses and infrastructure facilities required to sustain the day to day human activities.

\subsubsection{Water body}

The existence of open water in the study area is at the verge of extinction, as it has lost three-fourth part of its share from 1994 to 2018. According to estimates made from Landsat-5 TM it accounts for an area of $12.34 \%$ in 1994 , which reduced to $5.29 \%$ in $2002,3.5 \%$ in 2010 (Landsat-7 ETM+ estimates), and 3.18\% in 2018 (Landsat-8 OLI) (Figs. 2, 3a, 6, 7; Table 5). Thus, registering a negative growth rate of $74.30 \%$ (1994-2018), which is a matter of 
Table 3 Accuracy of LULC maps of Wular Lake obtained from satellite data for the selected time periods (1994, 2002,2010 , and 2018)

\begin{tabular}{|c|c|c|c|c|c|c|c|c|c|}
\hline Class & W & $M$ & A & $\mathrm{H}$ & $\mathrm{F}$ & $P$ & B & RT & UA \\
\hline \multicolumn{10}{|c|}{$\begin{array}{l}\text { Landsat-TM } 1994 \\
\text { (a) }\end{array}$} \\
\hline W & 93 & 7 & 0 & 0 & 0 & 0 & 0 & 100 & 93 \\
\hline$M$ & 12 & 85 & 3 & 0 & 0 & 0 & 0 & 100 & 85 \\
\hline A & 0 & 0 & 92 & 8 & 0 & 0 & 0 & 100 & 92 \\
\hline $\mathrm{H}$ & 0 & 0 & 15 & 85 & 0 & 0 & 0 & 100 & 85 \\
\hline $\mathrm{F}$ & 0 & 0 & 0 & 0 & 90 & 10 & 0 & 100 & 90 \\
\hline$P$ & 0 & 0 & 0 & 3 & 6 & 91 & 0 & 100 & 91 \\
\hline B & 0 & 0 & 0 & 0 & 0 & 0 & 100 & 100 & 100 \\
\hline $\mathrm{CT}$ & 105 & 92 & 110 & 96 & 96 & 101 & 100 & 700 & \\
\hline PA (\%) & 88.57 & 92.39 & 83.63 & 88.54 & 93.75 & 90.09 & 100 & & \\
\hline
\end{tabular}

Landsat-ETM +2002

(b)

$\begin{array}{llllllllll}\text { W } & \mathbf{8 9} & 11 & 0 & 0 & 0 & 0 & 0 & 100 & 89 \\ \text { M } & 6 & \mathbf{9 4} & 0 & 0 & 0 & 0 & 0 & 100 & 94 \\ \text { A } & 0 & 0 & \mathbf{9 0} & 10 & 0 & 0 & 0 & 100 & 90 \\ \text { H } & 0 & 0 & 4 & \mathbf{9 6} & 0 & 0 & 0 & 100 & 96 \\ \text { F } & 0 & 0 & 0 & 0 & \mathbf{8 8} & 12 & 0 & 100 & 88 \\ \text { P } & 0 & 0 & 0 & 0 & 0 & \mathbf{9 8} & 2 & 100 & 98 \\ \text { B } & 0 & 0 & 0 & 0 & 3 & 4 & 93 & 100 & 93 \\ \text { CT } & 95 & 105 & 94 & 106 & 91 & 114 & 95 & 700 & \\ \text { PA (\%) } & 93.6 & 89.52 & 95.74 & 90.56 & 96.7 & 85.96 & 97.89 & \end{array}$

Landsat-ETM +2010

(c)

$\begin{array}{llllllllll}\text { W } & \mathbf{9 4} & 6 & 0 & 0 & 0 & 0 & 0 & 100 & 94 \\ \text { M } & 9 & \mathbf{9 1} & 0 & 0 & 0 & 0 & 0 & 100 & 91 \\ \text { A } & 0 & 0 & \mathbf{9 1} & 9 & 0 & 0 & 0 & 100 & 91 \\ \text { H } & 0 & 0 & 12 & \mathbf{8 8} & 0 & 0 & 0 & 100 & 88 \\ \text { F } & 0 & 0 & 0 & 0 & 96 & 4 & 0 & 100 & 96 \\ \text { P } & 0 & 0 & 0 & 0 & 10 & 90 & 0 & 100 & 90 \\ \text { B } & 0 & 0 & 2 & 2 & 0 & 0 & 96 & 100 & 96 \\ \text { CT } & 103 & 97 & 105 & 99 & 106 & 94 & 96 & 700 & \\ \text { PA (\%) } & 91.26 & 93.81 & 86.66 & 88.88 & 90.56 & 95.74 & 100 & \end{array}$

Landsat-OLI 2018

(d)

$\begin{array}{llllllllll}\text { W } & \mathbf{1 0 0} & 0 & 0 & 0 & 0 & 0 & 0 & 100 & 100 \\ \mathrm{M} & 7 & \mathbf{9 3} & 0 & 0 & 0 & 0 & 0 & 100 & 93 \\ \mathrm{~A} & 0 & 1 & \mathbf{9 3} & 6 & 0 & 0 & 0 & 100 & 93 \\ \mathrm{H} & 0 & 0 & 4 & \mathbf{9 6} & 0 & 0 & 0 & 100 & 96 \\ \mathrm{~F} & 0 & 0 & 0 & 0 & \mathbf{9 3} & 7 & 0 & 100 & 93 \\ \mathrm{P} & 0 & 0 & 1 & 0 & 10 & \mathbf{8 9} & 0 & 100 & 89 \\ \mathrm{~B} & 0 & 0 & 2 & 0 & 0 & 1 & \mathbf{9 7} & 100 & 97 \\ \mathrm{CT} & 107 & 94 & 100 & 102 & 103 & 97 & 97 & 700 & \\ \mathrm{PA}(\%) & 93.45 & 98.93 & 93 & 94.11 & 90.29 & 91.75 & 100 & & \end{array}$

Diagonal Bold Italic numbers represent correctly classified samples for each LULC class

W: water body, M: marsh, A: agriculture, H: horticulture, F: forest, P: plantation, B: built-up, RT: row total, CT: column total, UA: user's accuracy, PA: producer's accuracy

(a) Sum of diagonals $=636$; Total $=700$; Overall accuracy $=90.85 \%$; Kappa coefficient $(K)=0.89$

(b) Sum of diagonals $=648$; Total $=700$; Overall accuracy $=92.57 \%$; Kappa coefficient $(K)=0.91$

(c) Sum of diagonals $=646$; Total $=700$; Overall accuracy $=92.28 \%$; Kappa coefficient $(K)=0.91$

(d) Sum of diagonals $=661$; Total $=700$; Overall accuracy $=94.42 \%$; Kappa coefficient $(K)=0.93$ 
Table 4 Accuracy of LULC maps of Hokersar and Anchar Lake obtained from satellite data for the selected time periods $(1994,2002,2010$, and 2018)

\begin{tabular}{|c|c|c|c|c|c|c|c|c|c|}
\hline Class & W & M & A & $\mathrm{H}$ & $\mathrm{F}$ & $\mathrm{P}$ & B & RT & UA \\
\hline \multicolumn{10}{|c|}{ Landsat-TM 1994} \\
\hline \multicolumn{10}{|l|}{ (a) } \\
\hline W & 100 & 0 & 0 & 0 & 0 & 0 & 0 & 100 & 100 \\
\hline M & 10 & 90 & 0 & 0 & 0 & 0 & 0 & 100 & 90 \\
\hline A & 0 & 0 & 94 & 6 & 0 & 0 & 0 & 100 & 94 \\
\hline $\mathrm{H}$ & 0 & 3 & 7 & 90 & 0 & 0 & 0 & 100 & 90 \\
\hline $\mathrm{F}$ & 0 & 0 & 0 & 0 & 92 & 8 & 0 & 100 & 92 \\
\hline$P$ & 0 & 0 & 1 & 0 & 12 & 87 & 0 & 100 & 87 \\
\hline B & 0 & 0 & 1 & 0 & 0 & 0 & 99 & 100 & 99 \\
\hline $\mathrm{CT}$ & 110 & 93 & 103 & 96 & 104 & 95 & 99 & 700 & \\
\hline PA (\%) & 90.9 & 96.77 & 91.26 & 93.75 & 88.46 & 91.57 & 100 & & \\
\hline
\end{tabular}

Landsat-ETM +2002

(b)

$\begin{array}{lllllllllr}\text { W } & \mathbf{1 0 0} & 0 & 0 & 0 & 0 & 0 & 0 & 100 & 100 \\ \mathrm{M} & 0 & \mathbf{1 0 0} & 0 & 0 & 0 & 0 & 0 & 100 & 100 \\ \mathrm{~A} & 0 & 0 & \mathbf{9 6} & 4 & 0 & 0 & 0 & 100 & 96 \\ \mathrm{H} & 0 & 2 & 8 & \mathbf{9 0} & 0 & 0 & 0 & 100 & 90 \\ \mathrm{~F} & 0 & 0 & 0 & 1 & \mathbf{9 1} & 8 & 0 & 100 & 91 \\ \mathrm{P} & 0 & 0 & 0 & 0 & 5 & \mathbf{9 4} & 1 & 100 & 94 \\ \mathrm{~B} & 0 & 0 & 6 & 1 & 0 & 4 & \mathbf{8 9} & 100 & 89 \\ \mathrm{CT} & 100 & 102 & 110 & 96 & 96 & 106 & 90 & 700 & \\ \mathrm{PA}(\%) & 100 & 98.03 & 87.27 & 93.75 & 94.79 & 88.67 & 98.88 & \end{array}$

Landsat-ETM +2010

(c)

$\begin{array}{lllllllllr}\text { W } & \mathbf{1 0 0} & 0 & 0 & 0 & 0 & 0 & 0 & 100 & 100 \\ \text { M } & 6 & \mathbf{9 4} & 0 & 0 & 0 & 0 & 0 & 100 & 94 \\ \text { A } & 0 & 0 & \mathbf{9 4} & 6 & 0 & 0 & 0 & 100 & 94 \\ \text { H } & 2 & 1 & 13 & \mathbf{8 4} & 0 & 0 & 0 & 100 & 84 \\ \text { F } & 0 & 0 & 0 & 0 & \mathbf{9 1} & 8 & 1 & 100 & 91 \\ \text { P } & 0 & 0 & 0 & 0 & 10 & \mathbf{8 7} & 3 & 100 & 87 \\ \text { B } & 0 & 0 & 6 & 2 & 0 & 2 & 90 & 100 & 90 \\ \text { CT } & 108 & 95 & 113 & 92 & 101 & 97 & 94 & 700 & \\ \text { PA (\%) } & 92.59 & 98.94 & 83.18 & 91.3 & 90.09 & 89.69 & 95.74 & \end{array}$

\begin{tabular}{llllllllll} 
(d) & & & & & & & & \\
W & $\mathbf{1 0 0}$ & 0 & 0 & 0 & 0 & 0 & 0 & 100 & 100 \\
M & 1 & $\mathbf{9 9}$ & 0 & 0 & 0 & 0 & 0 & 100 & 99 \\
A & 0 & 0 & $\mathbf{9 0}$ & 10 & 0 & 0 & 0 & 100 & 90 \\
H & 0 & 1 & 13 & $\mathbf{8 6}$ & 0 & 0 & 0 & 100 & 86 \\
F & 0 & 0 & 0 & 0 & $\mathbf{8 7}$ & 11 & 2 & 100 & 87 \\
P & 0 & 0 & 0 & 0 & 9 & 91 & 0 & 100 & 91 \\
B & 0 & 0 & 0 & 1 & 0 & 0 & 99 & 100 & 99 \\
CT & 101 & 100 & 103 & 97 & 96 & 102 & 101 & 700 & \\
PA (\%) & 99.01 & 99 & 87.37 & 88.65 & 90.62 & 89.21 & 98.01 & & \\
\hline
\end{tabular}

Diagonal Bold Italic numbers represent correctly classified samples for each LULC class

W: water body, M: marsh, A: agriculture, H: horticulture, F: forest, P: Plantation, B: built-up, RT: row total, CT: column total, UA: user's accuracy, PA: producer's accuracy

(a) Sum of diagonals $=640$; Total $=700$; Overall accuracy $=91.42 \%$; Kappa coefficient $(K)=0.9$

(b) Sum of diagonals $=652$; Total $=700$; Overall accuracy $=93.14 \%$; Kappa coefficient $(K)=0.92$

(c) Sum of diagonals $=640$; Total $=700$; Overall accuracy $=91.42 \%$; Kappa coefficient $(K)=0.9$

(d) Sum of diagonals $=660$; Total $=700$; Overall accuracy $=94.28 \%$; Kappa coefficient $(K)=0.93$ 

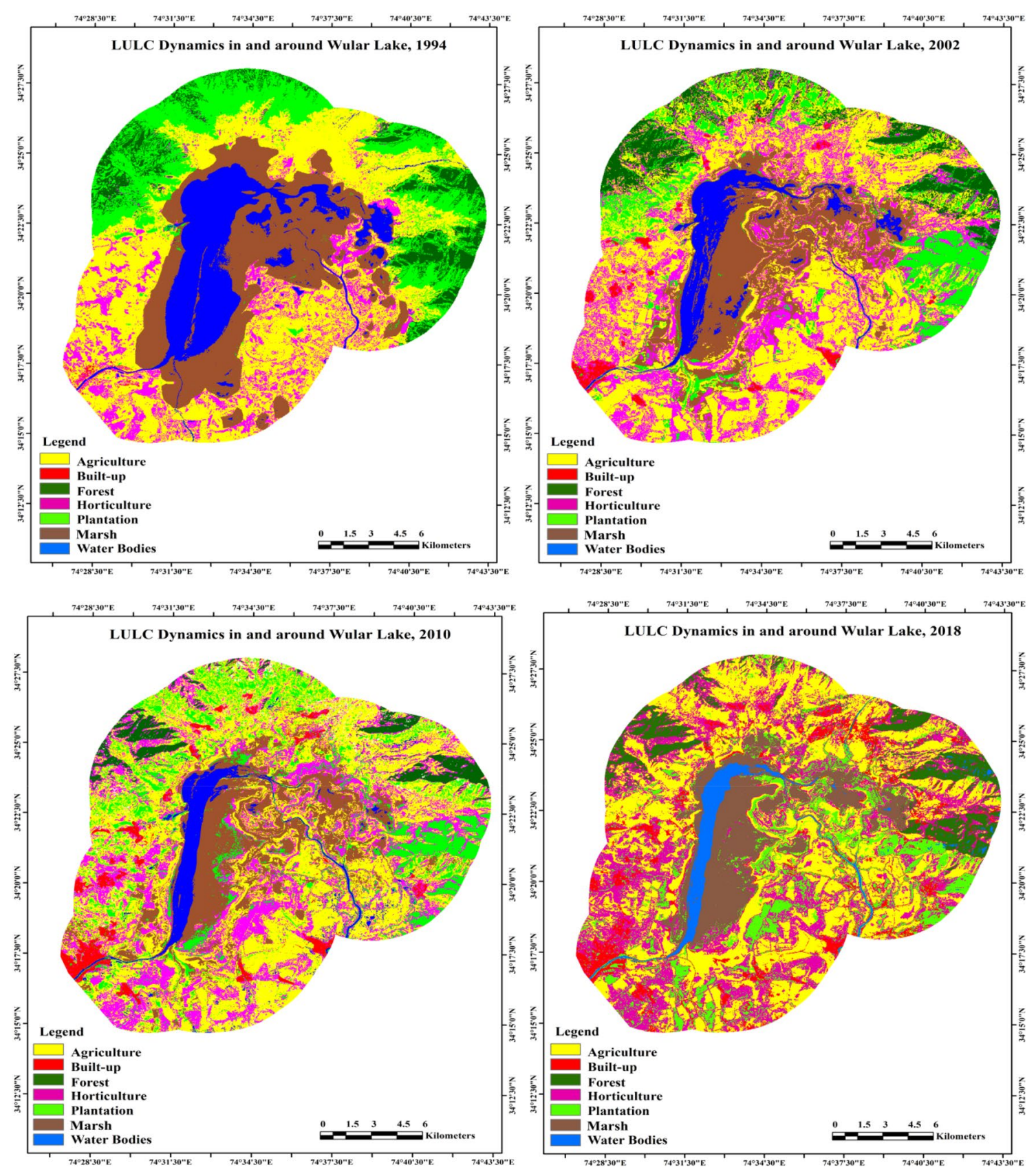

Fig. 2 LULC maps of Wular Lake (5 Sq. Km buffer) 1994, 2002, 2010, and 2018

great concern. The primary reason behind the shrinkage of the lake is the continuous inflow of sediments enhanced due to deforestation in its upper catchment areas resulting in loss of much of its water holding capacity and thus leading to continuous shrinkage of size. The sedimentation of water bodies in the long run degrade its aesthetic quality and aquatic environment [30]. River Jhelum along with its tributaries in its upper catchment bring down huge quantities of sediments especially in summer season along with snowmelt and rainwater of monsoons which get deposited directly into the lake. Apart from this, nutrients and organic matter, and untreated waste from domestic practices (settlements) are also getting deposited directly or indirectly into the lake which comes from upper catchment area of Jhelum River, surrounding fields and urban areas in the form of surface runoff, thus promoting the growth of aquatic vegetation in open water and promoting eutrophication and heavy metal contamination. Over the time, these areas became a part of human activities and were used for agricultural and plantation activities. 

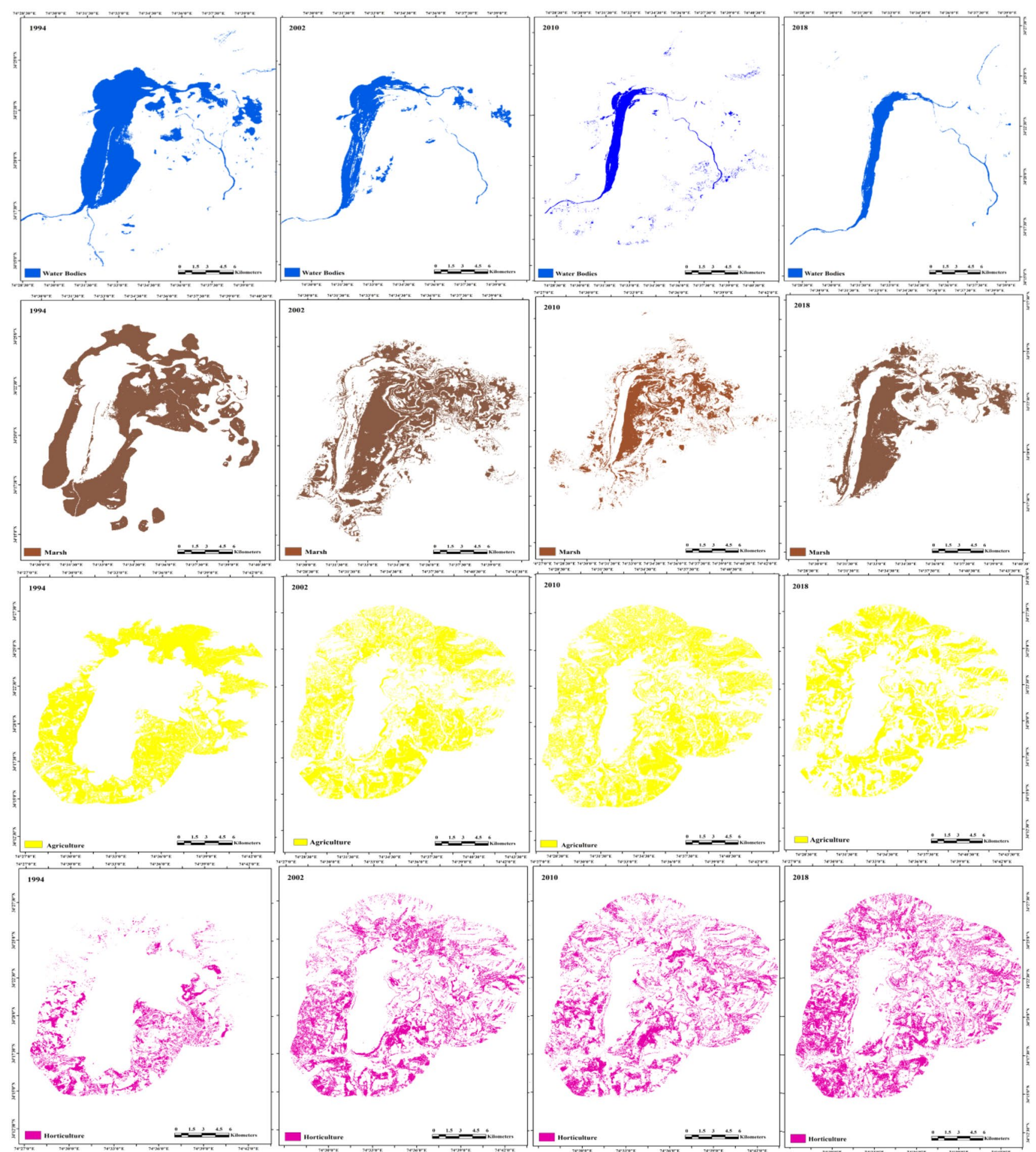

Fig. 3 LULC changes at different location in Wular Lake (5 Sq. km buffer) 1994-2002, 2002-2010, 2010-2018

\subsubsection{Marsh}

This LULC category represents the transition area between purely terrestrial and purely aquatic systems and are found in the low-lying terrain of the study area
(Fig. 2). Marshy area category depicts a decreasing trend in its share throughout the studied time period, registering a negative growth rate of $-44.13 \%$ from 1994 to 2018 , and has almost reduced to half of its share. It has held an area of about 8531.64 ha in $1994,7183.89$ ha 

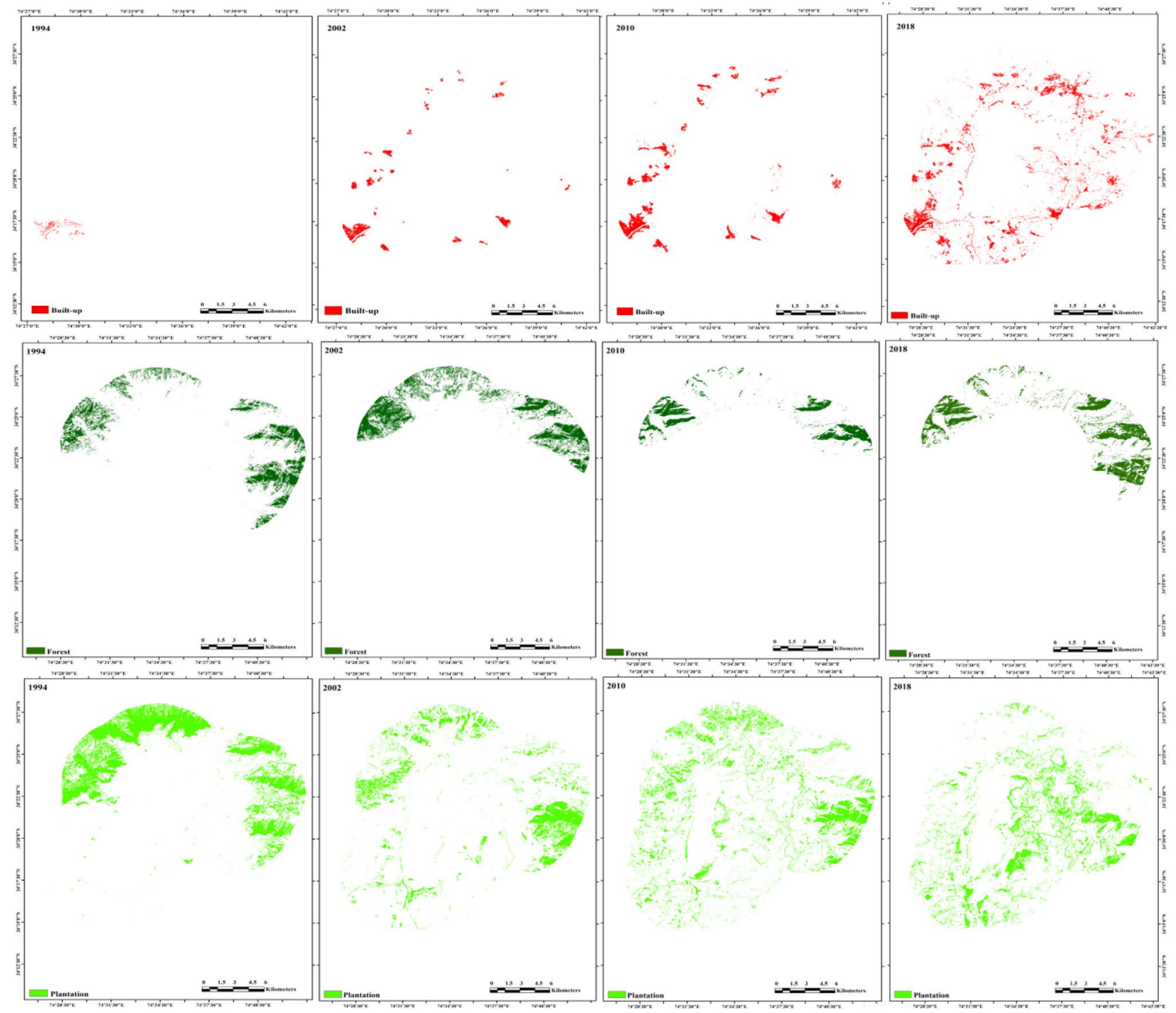

Fig. 3 (continued)

in $2002,6874.02$ in 2010 and 4766.56 ha in 2018 . The probable cause for this decrease is attributed to shrinkage of the lake causing the drying up of associated marshes making these bare. Reclamation and conversion of marshy lands for agricultural and horticultural activities in Wular environs has disbalanced its capacity to regulate the system and its flow regime resulting in increased flood and drought (NPCA 2019). Thus, the conversion of marshes into agricultural fields is directly associated with the increase in the growth rate of the human population and the requirement to meet the basic needs.

\subsubsection{Plantation}

The total area under plantation category constituted 7026.66 ha in the year $1994,4516.88$ ha in $2002,3113.19$ ha in 2010 , and 1648.48 ha in 2018), thus, revealing a decreasing trend in its share towards the total area under investigation (Figs. 2, 3b, 7; Table 5). The proposal of the government to remove willow trees from $27 \mathrm{Sq}$. Km area in which about 2.1 million willow trees were cut along with their rootstock to restore the ecological functioning of the lake by increasing its volumetric capacity (https://www.thehi ndu.com/sci-tech/energy-and-environment/willow-trees 

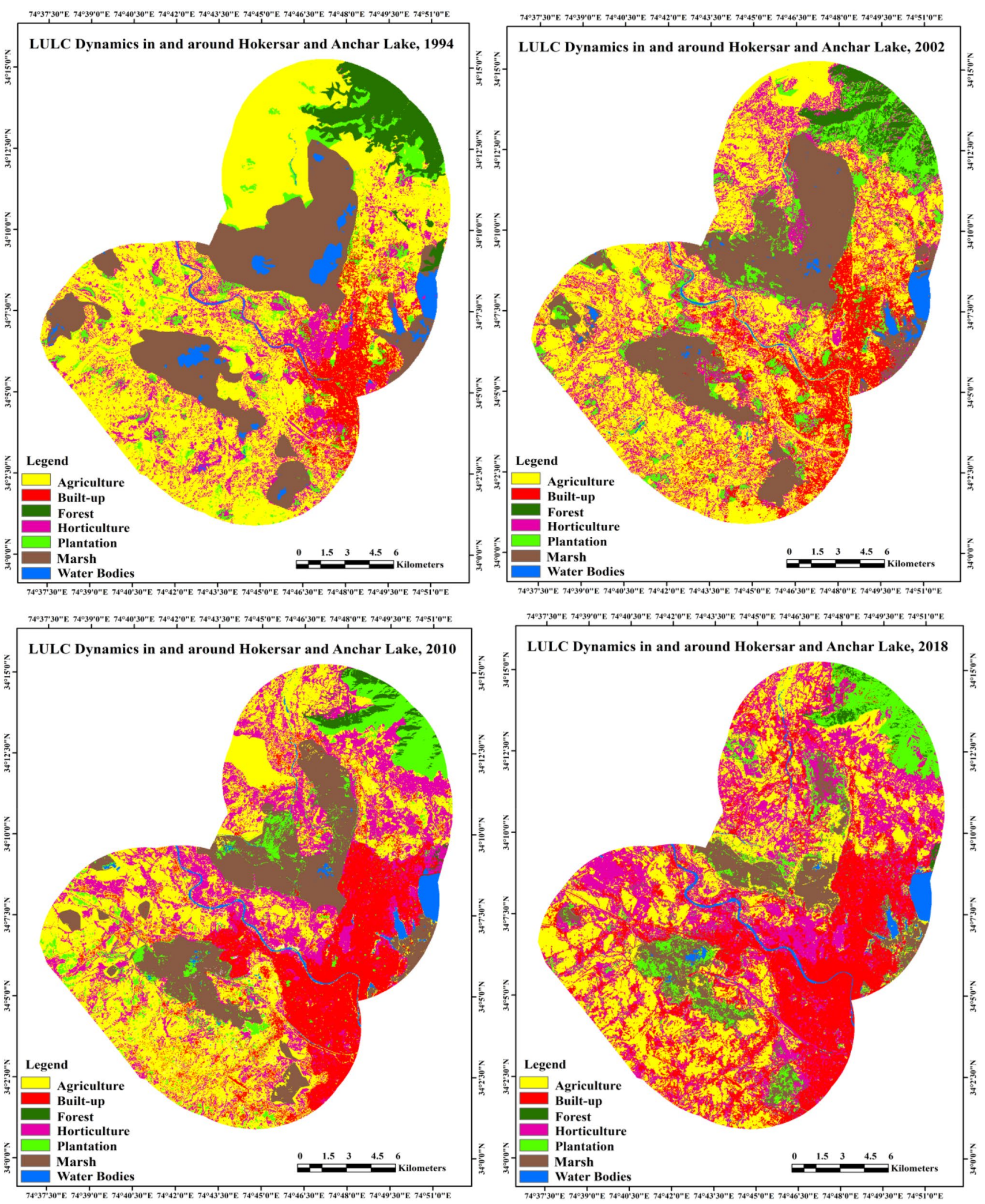

Fig. 4 LULC maps of Hokersar and Anchar Lake (5 Sq. km buffer) 1994, 2002, 2010, and 2018 

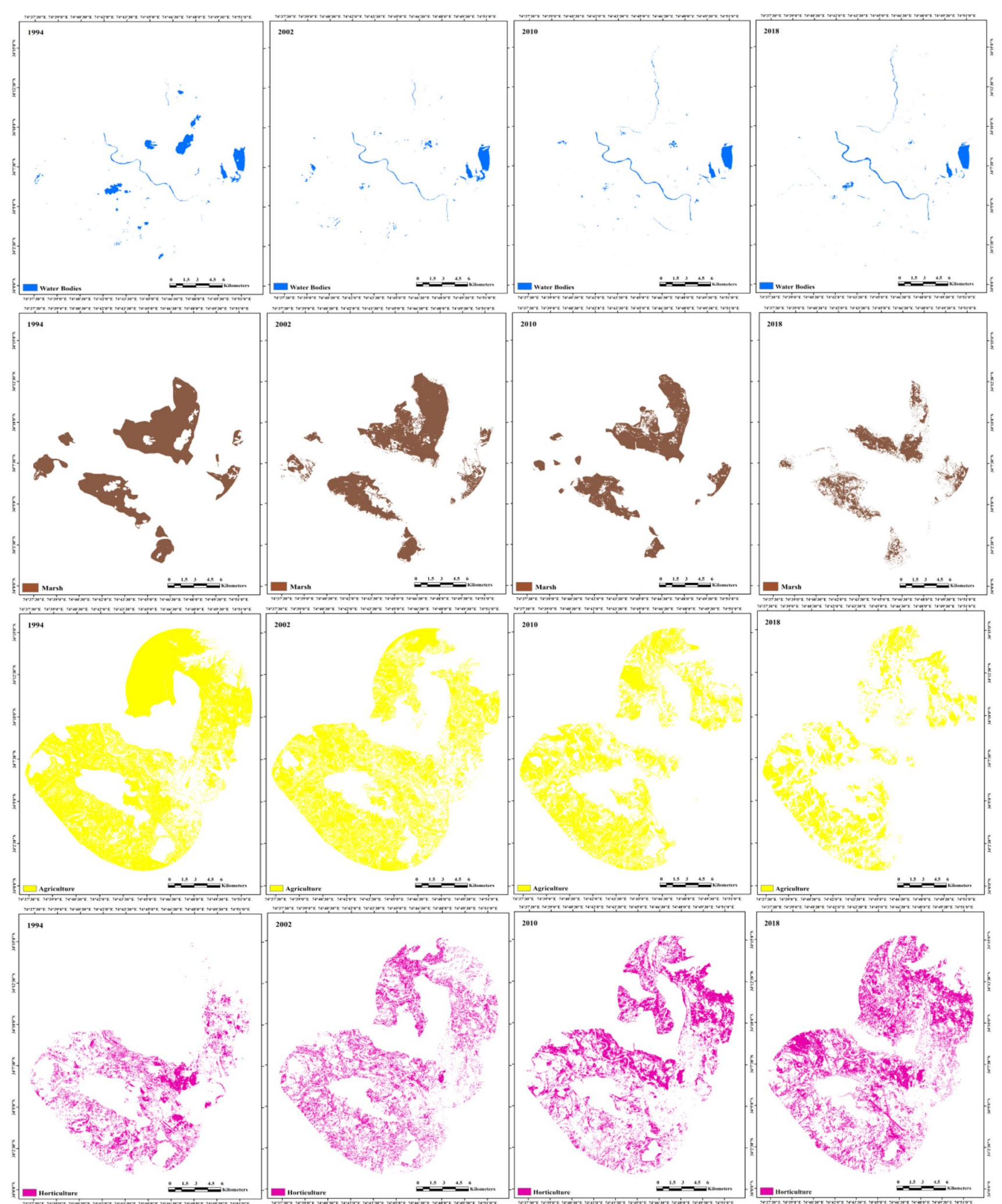

Fig. 5 LULC changes at different points of time in Hokersar and Anchar Lake (5 Sq. km buffer) 1994-2002, 2002-2010, 2010-2018 

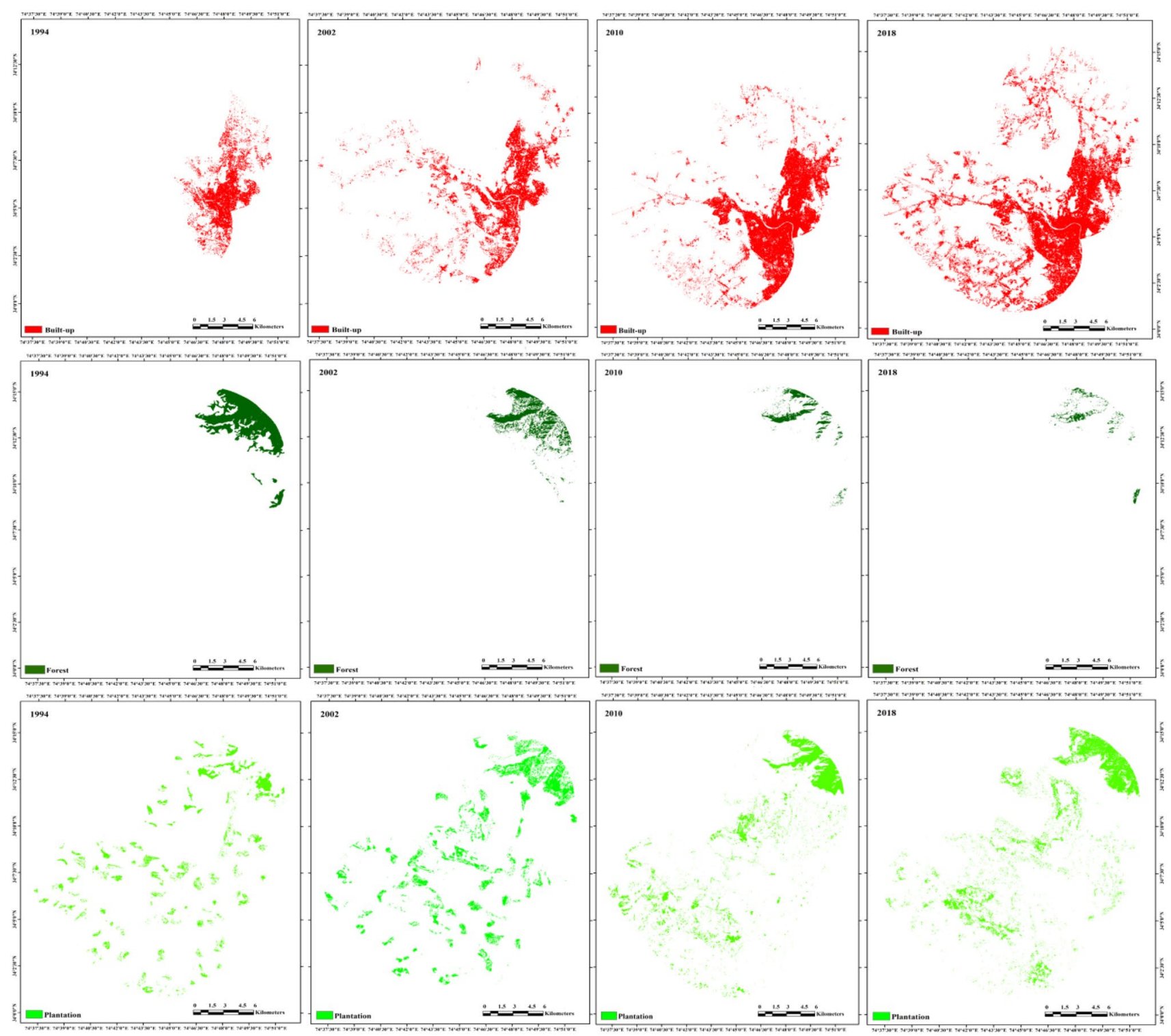

Fig. 5 (continued)

Table 5 LULC change statistics of Wular (in hectares) Source Compiled by the authors on basis of supervised classification of multi-temporal raster datasets

\begin{tabular}{|c|c|c|c|c|c|c|c|c|c|}
\hline Class & 1994 & 2002 & 2010 & 2018 & $\begin{array}{l}\text { Change } \\
\text { 1994-2002 }\end{array}$ & $\begin{array}{l}\text { Change } \\
\text { 2002-2010 }\end{array}$ & $\begin{array}{l}\text { Change } \\
\text { 2010-2018 }\end{array}$ & $\begin{array}{l}\text { Net change } \\
1994-2018\end{array}$ & $\begin{array}{l}\text { Net Change } \\
\text { (\%) 1994-2018 }\end{array}$ \\
\hline Forest & 2952.45 & 2866.71 & 2759.38 & 2501.60 & -85.74 & -107.33 & -257.78 & -450.85 & -15.27 \\
\hline Plantation & 7026.66 & 4516.88 & 3113.19 & 1648.48 & -2509.78 & -1403.69 & -1464.71 & -5378.18 & -76.54 \\
\hline Water body & 5322.78 & 2273.43 & 1516.18 & 1367.84 & -3049.35 & -757.25 & -148.34 & -3954.94 & -74.30 \\
\hline Marsh & 8531.64 & 7183.89 & 6874.02 & 4766.56 & -1347.75 & -309.87 & -2107.46 & -3765.08 & -44.13 \\
\hline Agriculture & $14,591.30$ & $16,291.10$ & $17,463.10$ & $18,409.83$ & 1699.80 & 1172.00 & 946.73 & 3818.53 & 26.17 \\
\hline Horticulture & 4466.80 & 9233.71 & 9954.51 & $11,641.60$ & 4766.91 & 720.80 & 1687.09 & 7174.8 & 160.63 \\
\hline Built-up & 77.31 & 603.22 & 1288.56 & 2633.49 & 525.91 & 685.34 & 1344.93 & 2556.18 & 3306.4 \\
\hline
\end{tabular}

\section{SN Applied Sciences}


Table 6 LULC change statistics of Hokersar and Anchar Lake (in hectares) Source Compiled by the authors on basis of supervised classification of multi-temporal raster datasets

\begin{tabular}{lccccccccc}
\hline Class & 1994 & 2002 & 2010 & 2018 & $\begin{array}{l}\text { Change } \\
1994-2002\end{array}$ & $\begin{array}{l}\text { Change } \\
2002-2010\end{array}$ & $\begin{array}{l}\text { Change } \\
2010-2018\end{array}$ & $\begin{array}{l}\text { Net change } \\
1994 \text { to } \\
2018\end{array}$ \\
& & & & & & & & $\begin{array}{l}\text { Net Change } \\
(\%)\end{array}$ \\
\hline Forest & 307.53 & 1051.84 & 2412.2 & 2583.09 & 744.31 & 1360.36 & 170.89 & 2275.56 & 739.95 \\
Plantation & 1203.66 & 1825.29 & 1877.56 & 3145.01 & 621.63 & 52.27 & 1267.45 & 1941.35 & 161.29 \\
Water body & 607.5 & 602.48 & 551.397 & 501.49 & -5.02 & -51.083 & -49.907 & -106.01 & -17.45 \\
Marsh & 7560 & 7002 & 5289.14 & 4098.27 & -558 & -1712.86 & -1190.87 & -3461.73 & -45.79 \\
Agriculture & $19,091.7$ & $15,248.8$ & $11,256.6$ & 7486.27 & -3842.9 & -3992.2 & -3770.33 & $-11,605.43$ & -60.79 \\
Horticulture & 5303.16 & 6570.18 & 8387.12 & $10,187.46$ & 1267.02 & 1816.94 & 1800.34 & 4884.3 & 92.10 \\
Built-up & 2084.31 & 3857.27 & 6383.84 & 8156.27 & 1772.96 & 2526.57 & 1772.43 & 6071.96 & 291.32 \\
\hline
\end{tabular}

Fig. 6 Area under different LULC classes of Wular Environs (1994, 2002, 2010 and 2018)
Fig. 7 Changes within each LULC class in Wular Environs (1994-2002-2010-2018)
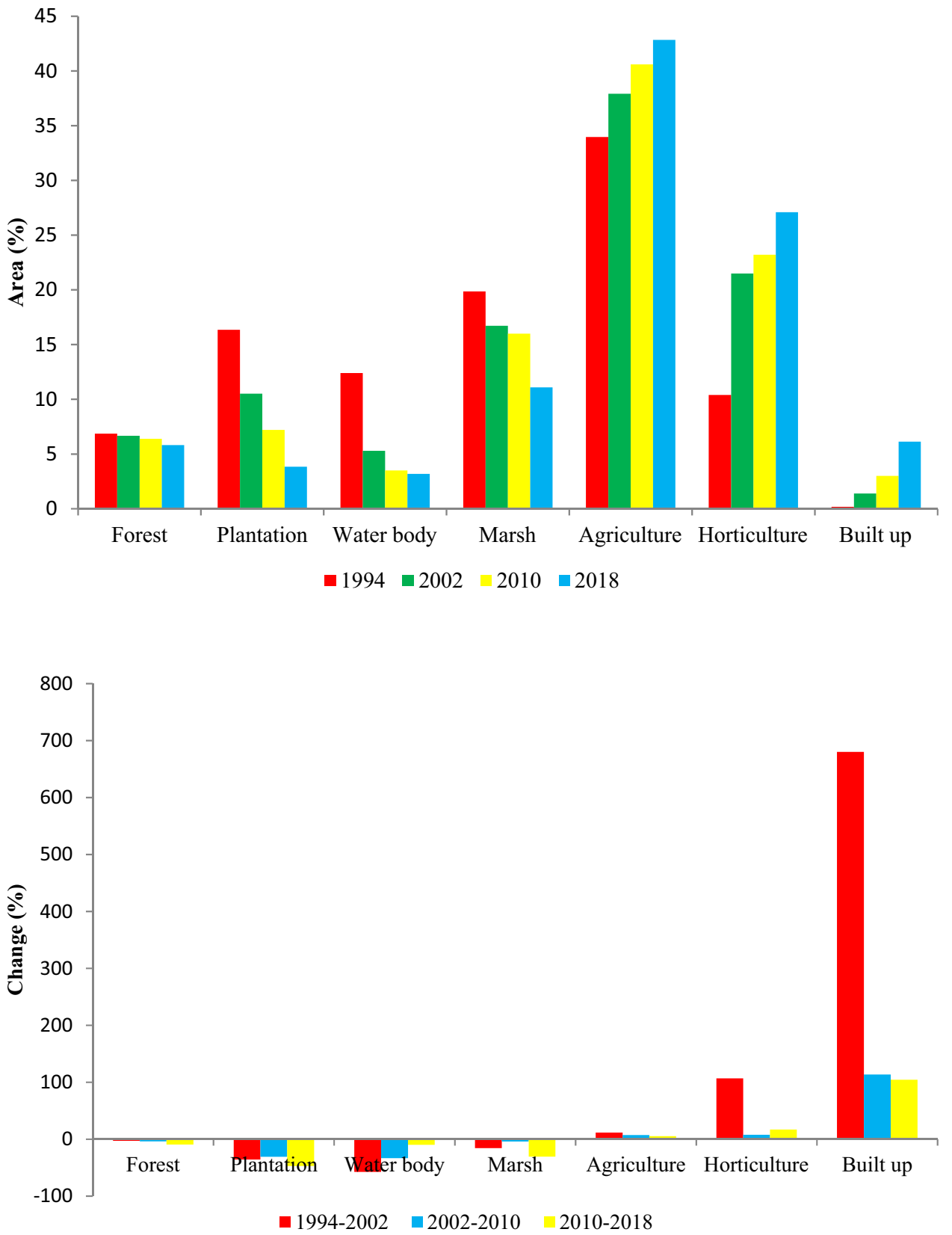
-caught-out-as-culprit-for-kashmir-lake-wulars-woes/artic le19767991.ece) is one of the major causes of decrease in this category. In addition to this the increasing demand for Kashmiri willow bats, apple boxes, fuel wood and other similar purposes are the probable reasons for the decreasing pattern of this class in the study area.

\subsubsection{Horticulture}

Horticulture (apple, pear, peach, almond, walnut, cherry and apricot) has shown an extensive and fast growth across the study area. This class of LULC engages about $60 \%$ of the population in the Valley. Among all the classes, horticulture has registered the maximum net growth rate of $160.63 \%$ from $1994-2018$. The analysis shows that horticulture has marked a significant positive change of about 4766.91 ha, taken place from 1994 to 2002 (Figs. 6, 7). Horticulture has gained most of its area from conversion of plantation and agricultural fields due to the inclination of farmers towards the cultivation of high yielding cash crops for higher economic returns, especially, apple cultivation.

\subsection{LULC of Hokersar and Anchar Lake}

\subsubsection{Agriculture}

Agriculture was the largest class in Hokersar and Anchar Lake in 1994, sharing an area of 19,091.7 ha (52.80\%) of the total area. However, it registered a continuous decline from 1994 to 2018 with a net growth (decline) rate of $-60.79 \%$. There has been a periodical decrease of 3842.9 ha (1994-2002), 3992.2 ha (2002-2010), and 3770.33 ha (2010-2018), (Figs. 4, 5a; Table 6). This decline is mainly due to conversion of paddy fields into apple orchards and expansion of built-up area as the area of concern lies mostly on the fringe of the capital city of Srinagar, where the demand of land is increasing by the day for the establishment of structures of commercial, residential and other infrastructural purposes at the cost of agricultural land.

\subsubsection{Forest}

The green gold in this study area observed a positive change of 2275.65 ha from 1994 to 2018 . It shared an area of $307.53 \mathrm{ha}(0.85 \%)$ in the year $1994,1051.84$ ha $(2.91 \%)$ in $2002,2412.2$ ha (6.67\%) in 2010, and 2583.09 ha (7.14) in 2018 (Table 6). Due to the establishment of law enforcing agencies and with their serious efforts, the cutting down of trees and plants falling under this category was reduced to a larger extent.

\subsubsection{Built-up}

The area under this category reveals a continuous increasing pattern during the selected time period. The analysis of the study area reveals that it shared an area of $5.76 \%$ in 1994 , which registered a tremendous increase to $22.56 \%$ in 2018, contributing to a positive net growth rate of 291.32\% (6071.96 ha) from 1994 to 2018 (Fig. 9; Table 6). This remarkable change was possible at the cost of loss of agricultural land, marshy land and water body categories. Due to the location of this area, in one of the most densely populated Himalayan region where the expansion of the primate city (Srinagar) is primarily horizontal, leading to encroachments in Hokersar and Anchar Lake environs. Such infringements and poor management practices are the main driving factors for degradation of these essential aquatic ecosystems.

\subsubsection{Water body}

This LULC class is the smallest category of this classification, contributing 607.5 ha $(1.68 \%), 602.48$ ha $(1.67 \%)$, 551.397 ha $(1.52 \%)$, and 501.49 ha $(1.39 \%)$ in the years 1994, 2002, 2010 and 2018, respectively (Figs. 4, 5a; Table 6), thus registering a continuous decline in its area with a net negative growth rate of $17.45 \%$ from 1994 to 2018. Such changes in a water body can be attributed to human intervention in the catchment, climate change leading to fluctuations in water budget, increasing siltation, land reclamation and use of wetlands for waste dumping purposes by people living on the edges of these wetlands.

\subsubsection{Marsh}

This LULC category marked a negative growth constituting $7560 \mathrm{ha}, 7002 \mathrm{ha}, 5289.14 \mathrm{ha}$, and $4098.27 \mathrm{ha}$ in 1994 , 2002, 2010 and 2018, respectively (Figs. 4, 5a, 8, 9; Table 6). The statistics of trend observation of the present study is in agreement with the previous studies conducted on Hokersar wetland (e.g., [3]). The encroachments for the purpose of increased agricultural practices and plantation (particularly willow) in the study area have resulted in the loss of marshy area.

\subsubsection{Plantation}

The plantation depicts a continuous increasing trend in its spatial dimensions. It registered an area of $1203.66 \mathrm{ha}$ (3.33\%) in 1994 which increased to 3145.01 ha in 2018. The rate of change in this category as depicted by classification of multi-date raster layers was $621.63 \mathrm{ha}$ (1994-2002), 52.27 ha (2002-2010), and 1267.45 ha (2010-2018). 
Fig. 8 Area under different LULC classes of Hokersar and Anchar Lake Environs (1994, 2002, 2010 and 2018)
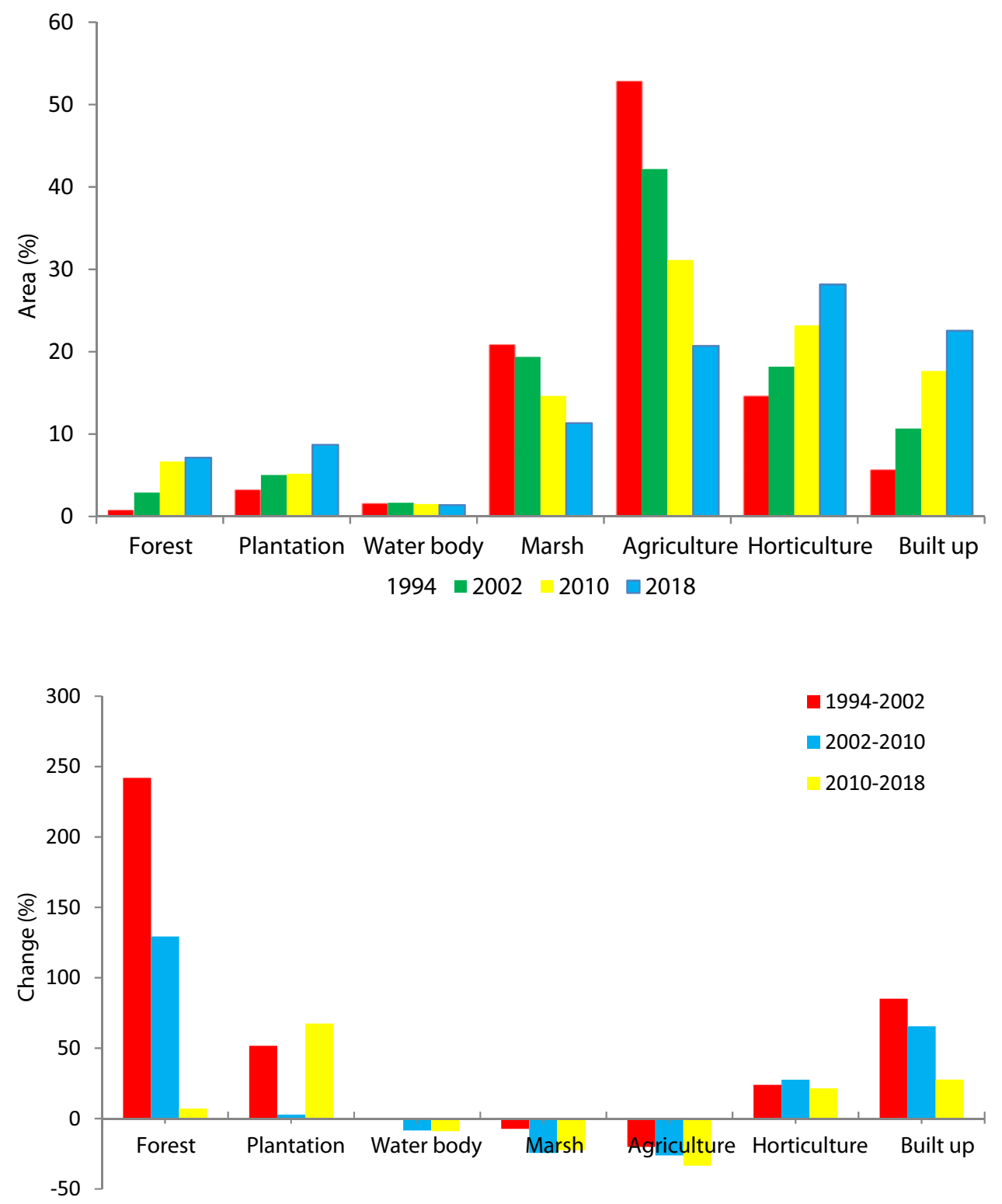

Fig. 9 Changes within each LULC class in Hokersar and Anchar Lake Environs (19942002-2010-2018)

\subsubsection{Horticulture}

Again, horticulture noticed an increasing pattern with a net change of 4884.3 ha from 1994 to 2018 in this area of investigation as well. The share of this class out of the total area was found to be 5303.16 ha $(14.67 \%), 6570.18$ ha (18.17\%), 8387.12 ha (23.20\%) and $10,187.46$ ha $(28.17 \%)$ in the years 1994, 2002, 2010 and 2018, respectively (Figs. 8, 9; Table 6).

\subsection{Land transformation in the study area}

The analysis of Tables 7, 8 and Figs. 10, 11, shows that significant LULC change both positive and negative during three decades occurred in the study area. To understand the type and extent of land encroachment in last three decades (1994-2018), it was imperative to prepare a change detection matrix (Table 7 and 8).

\subsubsection{LULC transformations in Wular environs}

The analysis of the transformation matrix of Wular environs (Table 7) reveals that:

i. About 65 ha area of forest cover has been occupied by plantation, 50 ha by marsh, 883 ha by agriculture, 710 ha by horticulture, and 11 ha by built-up category in last three decades from 1994 to 2018.

ii. About 740 ha, 16 ha, 4286 ha, 1613 ha, and 112 ha of plantation area has been transformed into forest, marsh, agriculture, horticulture and built-up categories in Wular lake during the studied time period. 
Table 7 Transformation matrix of Wular (1994-2018)

\begin{tabular}{|c|c|c|c|c|c|c|c|c|c|}
\hline & \multirow{2}{*}{ Classes } & \multicolumn{8}{|c|}{1994 (Hectare) } \\
\hline & & Forest & Plantation & Water body & Marsh & Agriculture & Horticulture & Built-up & Total 2018 \\
\hline \multirow{8}{*}{ 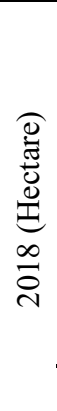 } & Forest & 1230.7 & 740.64 & 103.32 & 145.32 & 91.78 & 189.842 & 0 & 2501.6 \\
\hline & Plantation & 65.003 & 256.568 & 130.32 & 710.86 & 331.96 & 153.707 & 0 & 1648.42 \\
\hline & Water body & 0 & 0 & 1234.87 & 119.42 & 0.6 & 12.955 & 0 & 1367.84 \\
\hline & Marsh & 50.935 & 16.875 & 3326.49 & 1283.7 & 0 & 88.5275 & 0 & 4766.51 \\
\hline & Agriculture & 883.66 & 4286.09 & 232.952 & 3903.2 & 7500.2 & 1603.7 & 0 & 18409.8 \\
\hline & Horticulture & 710.65 & 1613.99 & 253.77 & 1995.3 & 5084.07 & 1983.5 & 0 & 11641.3 \\
\hline & Built-up & 11.508 & 112.5 & 41.0625 & 373.83 & 1582.69 & 434.572 & 77.31 & 2633.47 \\
\hline & Total 1994 & 2952.5 & 7026.66 & 5322.78 & 8531.6 & 14591.3 & 4466.8 & 77.31 & 42968.95 \\
\hline
\end{tabular}

Table 8 Transformation matrix of Hokersar and Anchar Lake

\begin{tabular}{|c|c|c|c|c|c|c|c|c|c|}
\hline & \multirow[b]{2}{*}{ Classes } & \multicolumn{8}{|c|}{1994 (Hectare) } \\
\hline & & Forest & Plantation & Water body & Marsh & Agriculture & Horticulture & $\begin{array}{c}\text { Built } \\
\text { up }\end{array}$ & Total 2018 \\
\hline \multirow{8}{*}{ 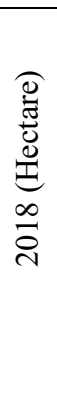 } & Forest & 44.975 & 122.5825 & 45.175 & 1377.7 & 987.165 & 5.5125 & 0 & 2583.09 \\
\hline & Plantation & 244.978 & 707.058 & 18.2475 & 1130.3 & 829.058 & 215.4 & 0 & 3145.01 \\
\hline & Water body & 0 & 0.2925 & 407.38 & 65.073 & 1.8825 & 26.86 & 0 & 501.49 \\
\hline & Marsh & 0 & 0.995 & 67.53 & 2750.9 & 181.17 & 1097.63 & 0 & 4098.27 \\
\hline & Agriculture & 1.65 & 238.183 & 41.715 & 404.66 & 6767.11 & 32.9525 & 0 & 7486.27 \\
\hline & Horticulture & 11.79 & 109.775 & 15.615 & 1529.8 & 6105.91 & 2414.62 & 0 & 10187.46 \\
\hline & Built up & 4.14 & 24.7725 & 11.835 & 301.63 & 4219.4 & 1510.18 & 2084.3 & 8156.26 \\
\hline & Total 1994 & 307.53 & 1203.66 & 607.5 & 7560 & 19091.7 & 5303.16 & 2084.3 & 36157.85 \\
\hline
\end{tabular}

Fig. 10 Wular change map 1994-2018

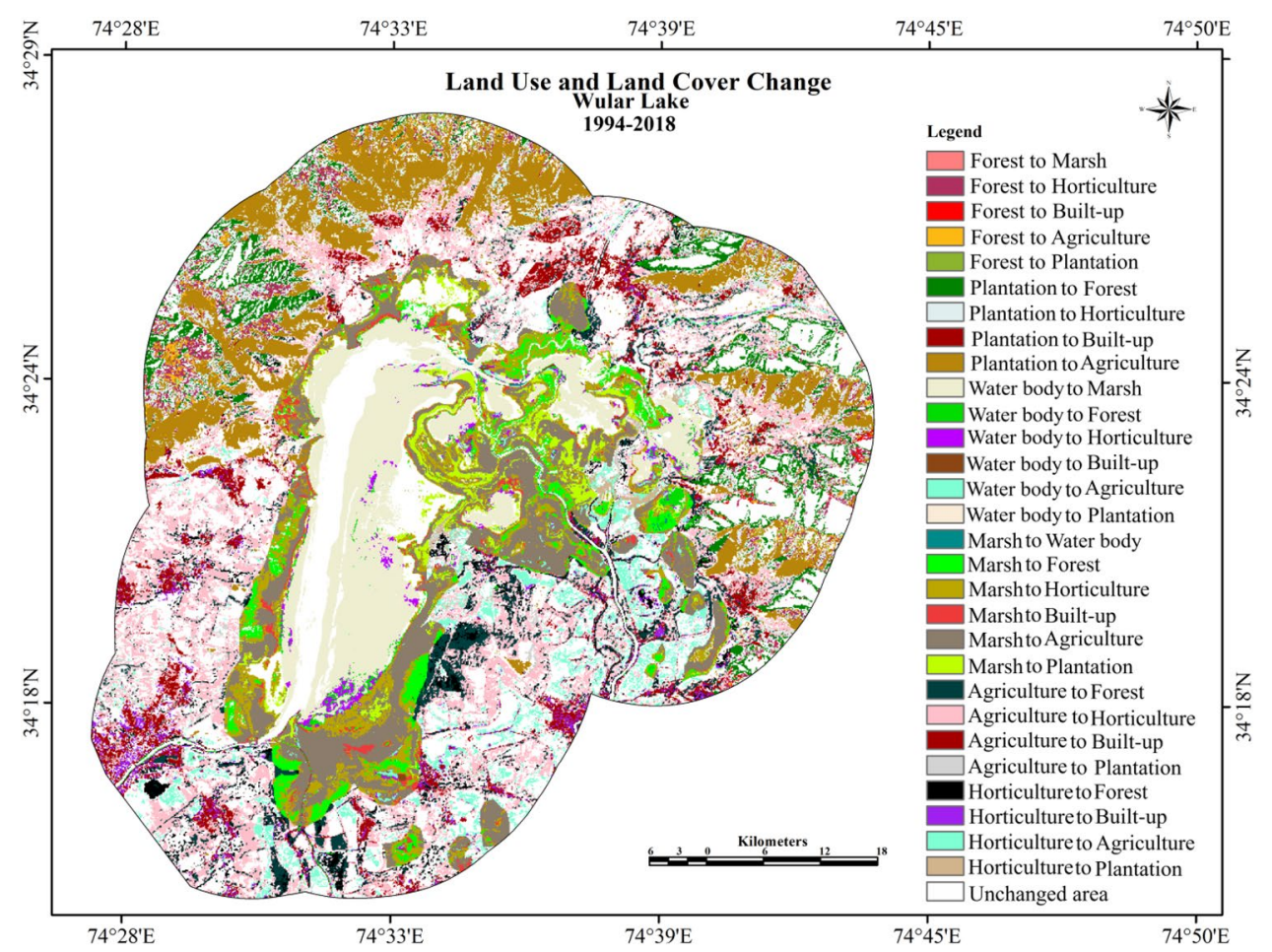


Fig. 11 Hokersar and Anchar change map 1994-2018

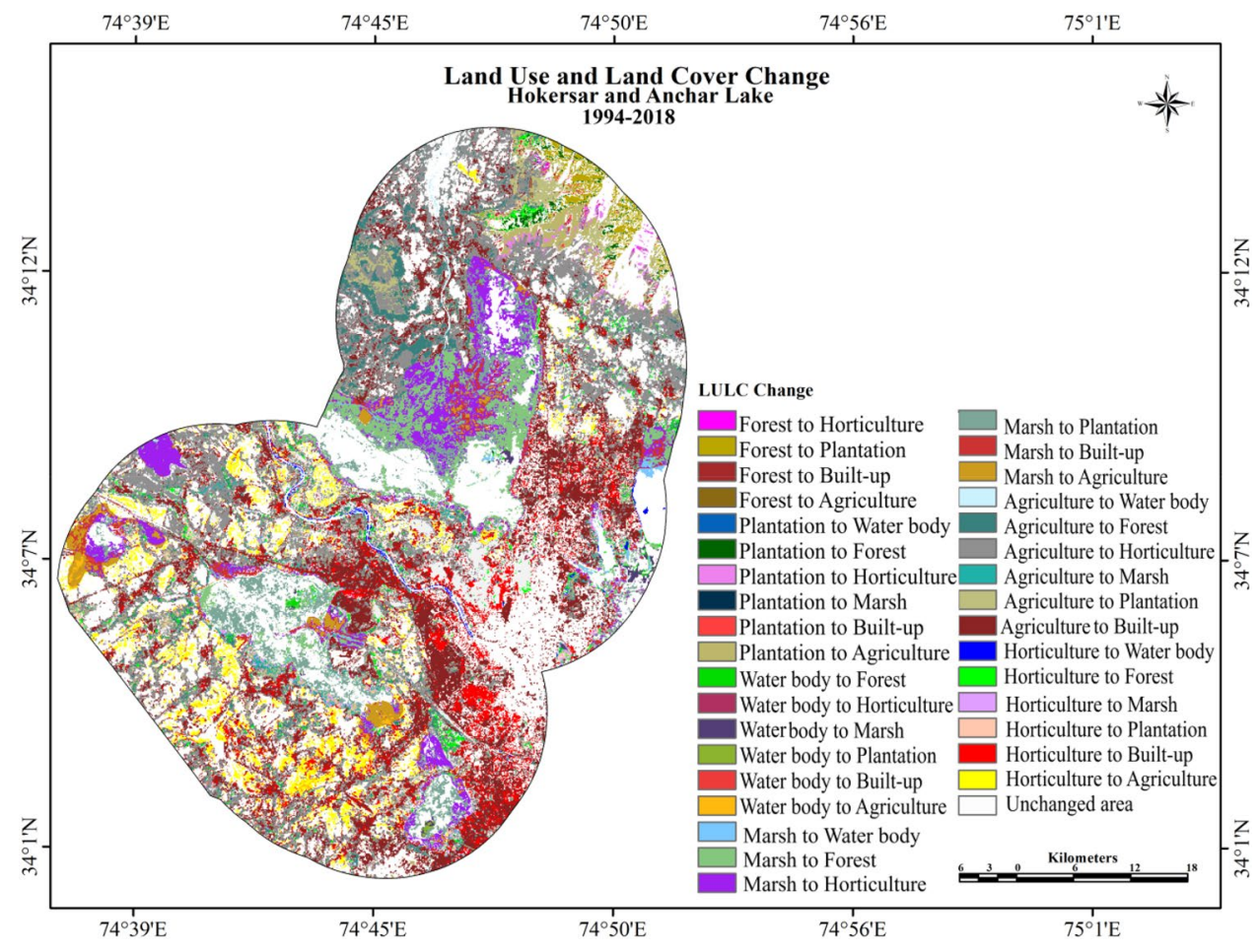

iii. About 1234 ha of the area of the water body of Wular lake is found unchanged, and the rest has been converted into six other categories with maximum area of 3326.49 ha under marsh category from 1994 to 2018.

iv. Similarly, marsh, agriculture, and horticulture have revealed a significant transformation in their respective areas. Out of 8531.64 ha of marsh, $14,591.3$ ha of agriculture, 4466.8 ha of horticulture only 1283.68 ha, 7500.2 ha, 1983.5 ha, respectively, remain unchanged during the studied time period in Wular lake.

\subsubsection{LULC transformations in Hokersar and Anchar environs}

Change matrix of Hokesar and Anchar environs (1994-2018) states that (Table 8):

i. Forest area category lost its $1.65 \mathrm{ha}$ area to agriculture, 11.79 ha to horticulture, 244.978 ha to plantation and 4.14 ha to built-up from 1994 to 2018.

ii. About 122 ha of plantation has been converted into forest, 238.183 ha to agriculture, 109 ha to horticulture and about 25 ha into built-up.

iii. About 200 ha of water body has been converted into plantation, forest, agriculture, horticulture, marsh and built-up during the last three decades. iv. Similarly, agriculture, horticulture and marsh categories have undergone land encroachments over the time period of study from 1994 to 2018.

\section{Trend analysis of land cover types (1994- 2018)}

This section looks at the trends (direction and scale) of land use changes by using land use statistics of area in and around Wular, Hokersar and Anchar Lakes for over a period of time. Here, regression analysis model was used which has a very flexible design and can be used with data that are not evenly spaced over time. Generally, land use trends are continuously structured by the changing man-environment interactions, changing nature of economic activities and many times due to policies of a region. Here in case of Wular, Hokersar and Anchar Lakes it is observed that over time each of the land use category revealed either its share of growing or declining trends (Figs. 12a, b, 13a, b) that may be the result of climate change, changing socioeconomic and other associated activities during 1994 to 2018.

\subsection{Wular Lake trend analysis}

Figure 12a shows the scatter plot of land area under forest, plantation, water body and marshes (from 1994 to 2018) reveals a declining trend over time and is a stationary data 
(a)

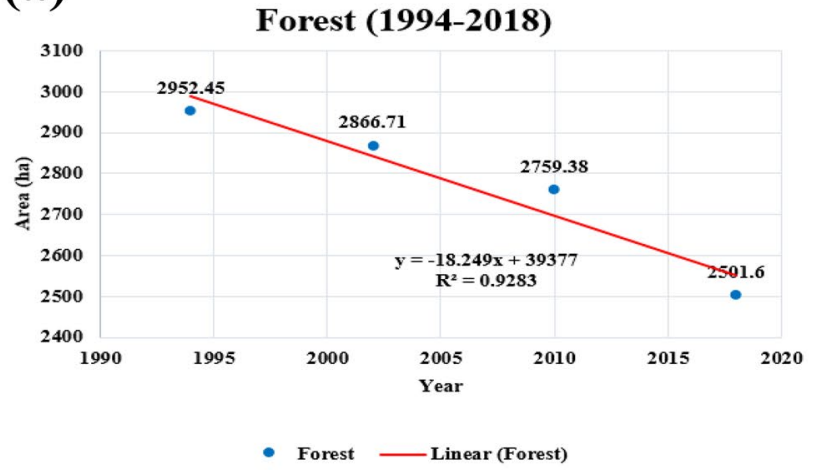

Water body (1994-2018)

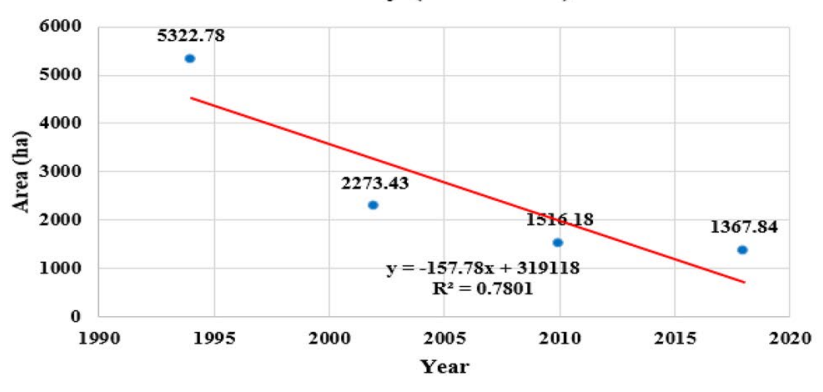

- Water body Linear (Water body)

(b)

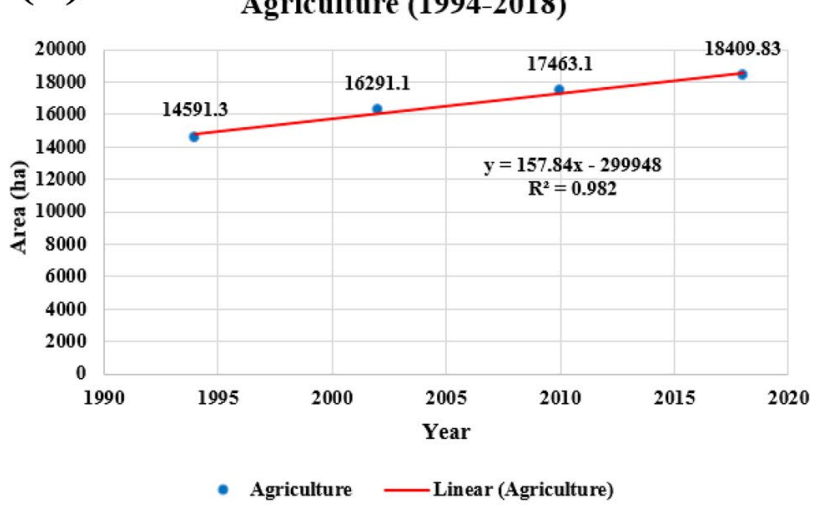

Plantation (1994-2018)

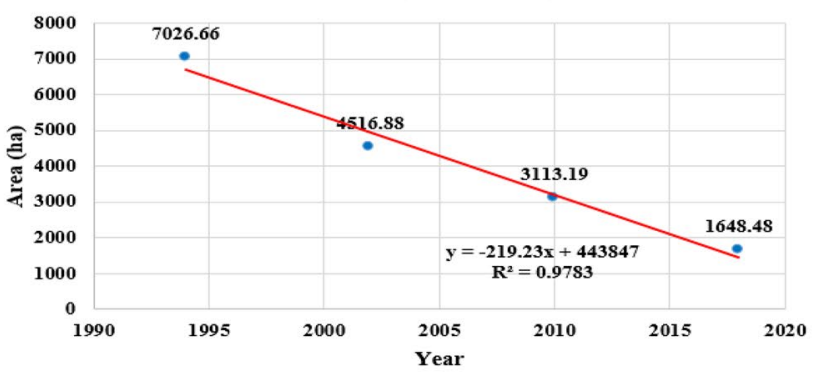

- Plantation Linear (Plantation)

Marsh (1994-2018)

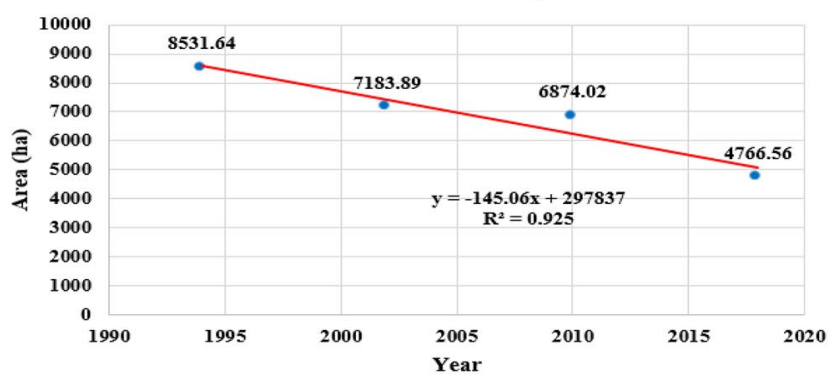

- Marsh Linear (Marsh)

\section{Horticulture (1994-2018)}

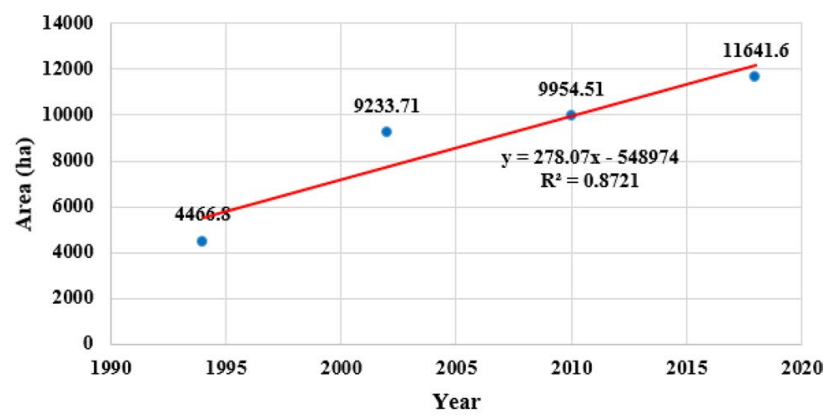

- Horticulture Linear (Horticulture)

\section{Built-Up (1994-2018)}

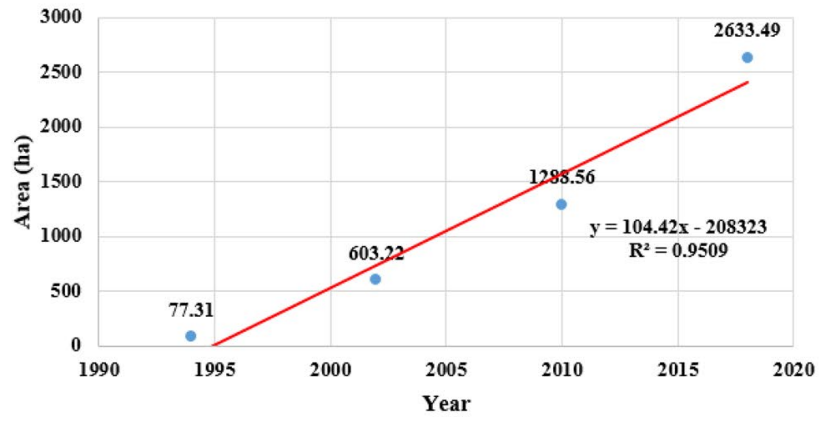

- Built-up Linear (Built-up)

Fig. 12 Trend analysis of LULC categories of Wular Lake, 1994-2018 


\section{(a)}

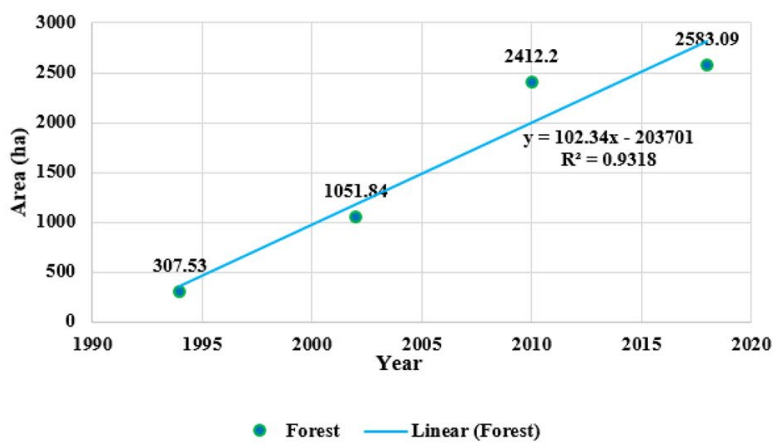

Water body (1994-2018)

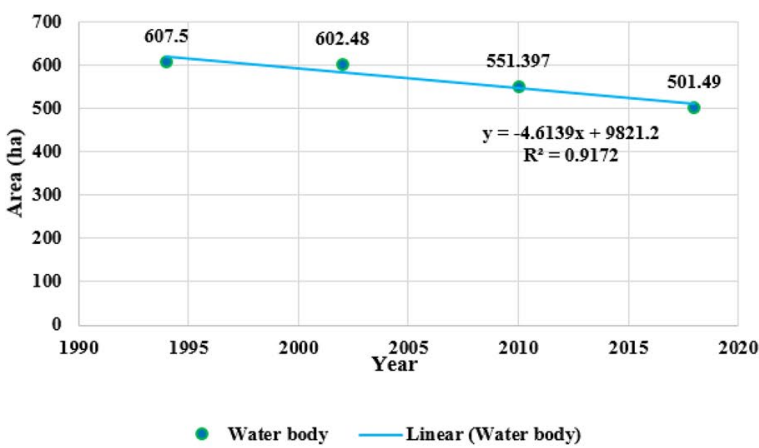

(b)

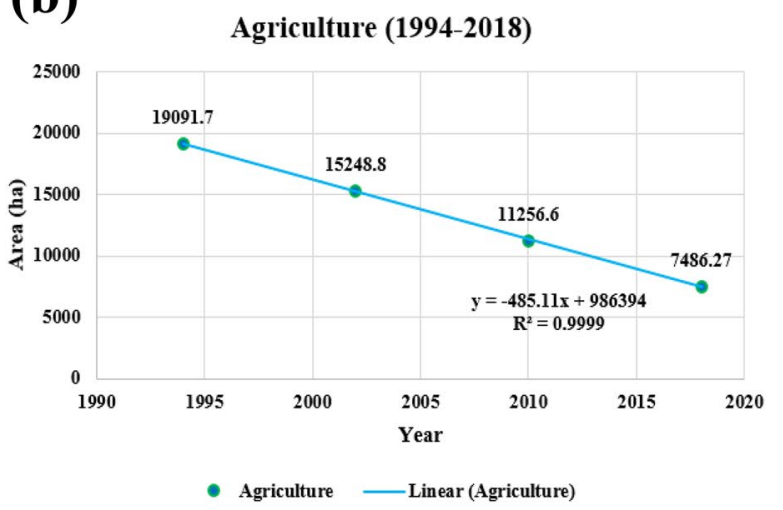

Plantation (1994-2014)

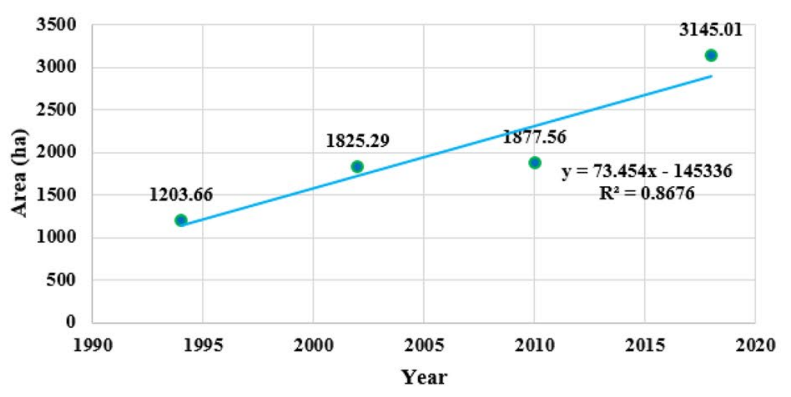

- Plantation Linear (Plantation)

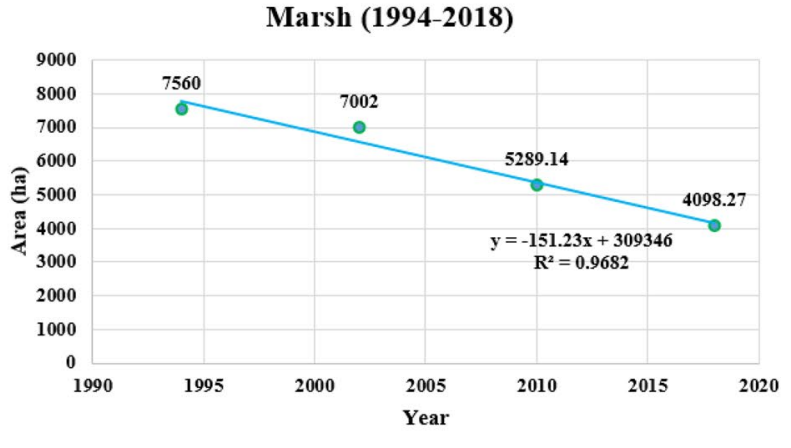

- Marsh Linear (Marsh)

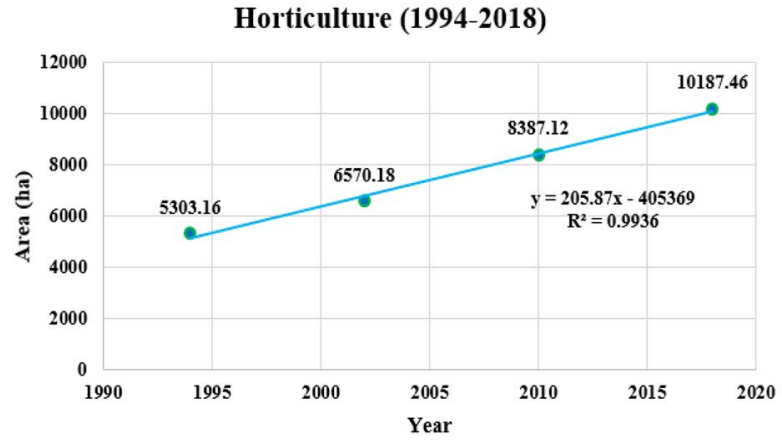

- Horticulture Linear (Horticulture)

\section{Built-Up (1994-2018)}

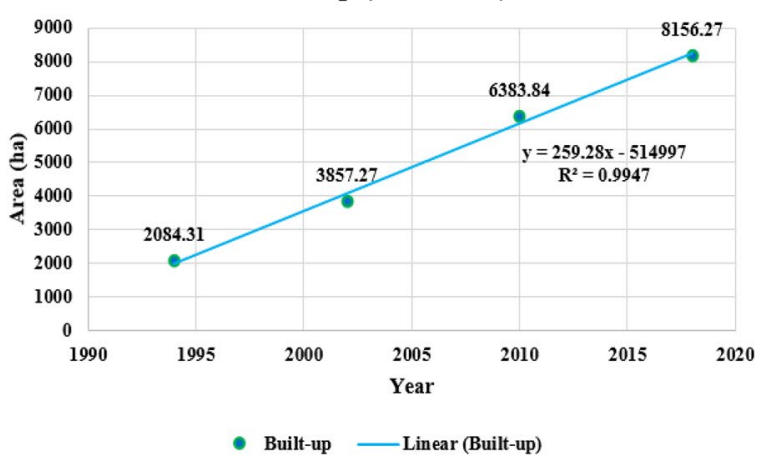

Fig. 13 Trend analysis of LULC categories of Hokersar and Anchar Lake, 1994-2018 
series, while scatter plot for agriculture, horticulture and built-up area (Fig. 12b) shows an upward trend and is a stationary data series revealing change in socioeconomic activities at priorities on the cost of engulfing areas under forest, water bodies and marsh. The results of regression analysis show that area under forest $\left(R^{2}=0.928\right)$, plantation $\left(R^{2}=0.978\right)$, water body $\left(R^{2}=0.780\right)$ and marsh $\left(R^{2}=0.925\right)$ within the time period under consideration (1994-2018) has significant inverse correlation (Fig. 11a, b), while agriculture $\left(R^{2}=0.982\right)$, horticulture $\left(R^{2}=0.872\right)$ and built-up $\left(R^{2}=0.95\right)$ area has direct correlation within same time period. The comparison of coefficient of regression function highlights that the area under forest, plantation, water body, and marsh around Wular Lake is severely affected during 1994 to 2018. The increase in agriculture, horticulture, and built-up area around these land use/cover types might have led to reduction in the area under forest, plantation, water body and marsh during 1994-2018.

\subsection{Hokersar and Anchar Lake trend analysis}

The trend analysis for Hokersar and Anchar Lake shows a somewhat different picture. Here, Fig. 13a, b shows the scatter plot of land area under water body, marsh and agriculture from 1994 to 2018 revealing a declining trend over time while scatter plot for forest plantation, horticulture and built-up area (Fig. 13a, b) show upward trend revealing changes in socioeconomic activities at priorities on the cost of engulfing area under water body, marsh and agriculture. Similarly, the results of regression analysis exhibit the area under water body $\left(R^{2}=0.917\right)$, marsh $\left(R^{2}=0.968\right)$, and agriculture $\left(R^{2}=0.999\right)$ within the time period $1994-2018$ have strong inverse correlation, while, the forest $\left(R^{2}=0.931\right)$, plantation $\left(R^{2}=0.876\right)$, horticulture $\left(R^{2}=0.993\right)$ and built-up $\left(R^{2}=0.994\right)$ area have significant direct/positive correlation within the same time period. The comparison of coefficient of regression function highlights that the area under water body, marsh, and agriculture around Hokersar and Anchar Lake has been severely affected during 1994 to 2018. The increase in forest plantation, horticulture, and built-up area around these land use/cover types might have led to reduction of the area under water body, marsh, and agriculture during 1994-2018.

From the above regression analysis, it can be concluded that the land use trends are continuously shaped over time with major and minor transformations from one category to the other.

\section{Conclusion}

This study quantitatively demonstrates the pattern of LULC dynamics in and around the wetland ecosystems of Kashmir Valley using Landsat data enabled with remote sensing and GIS techniques from 1994 to 2018. The results of the study reveal that the area of concern has undergone massive LULC changes over the last three decades. The classified raster layers reveal that agriculture is the most dominant land use around Wular Lake, followed by horticulture and marsh. The area under forest, plantation, water body and marsh display a negative trend in Wular environs from 1994 to 2018, with a net change of $-450.85 \mathrm{ha},-5378.15 \mathrm{ha},-3954.94 \mathrm{ha}$, and -3765.08 ha, respectively. Similarly, in Hokersar and Anchar lake environs, water body, marsh, and agriculture show a net change of -106.01 ha, -3461.73 ha, and $-11,605.43$ ha, respectively. However, the classes which exhibited an increasing trend in Wular are agriculture, horticulture, and built-up area, the net positive change in these LULC classes from 1994 to 2018 has been $+3818.53 \mathrm{ha},+7174.8 \mathrm{ha}$, and 2556.18 ha, respectively. Also, in case of Hokersar and Anchar, forest, plantation, horticulture, and built-up area exhibited a net positive change of $2275.56 \mathrm{ha}, 1941.35 \mathrm{ha}, 4884.3 \mathrm{ha}$, and $6071.96 \mathrm{ha}$, respectively with an increasing trend. The assessment of the study reveals that LULC changes in wetland environs of Kashmir Valley have been identified as the main driving force behind degradation of wetland ecosystem. In the last three decades, these aquatic ecosystems of the study area have suffered devastating and diminishing impacts on their spatial extent, water quality and ecosystem functioning as a result of changing LULC triggered by unplanned urban expansion, unregulated agricultural and horticultural development, inflow of silt, insecticides, pesticides, fertilizers, solid waste materials, domestic and industrial pollutants and ill-planned policies, resulting in wide range of adverse environmental impacts. Thus, the wetland ecosystems of Kashmir Valley are threatened by these anthropogenic activities like urban development, agriculture and horticulture practices, impacts of insecticides and pesticides, fertilizers, climate change and invasion of alien species. To comprehend the scenario more thoroughly, subsequent assessment of wetland dynamics, anthropogenic activities, landscape monitoring, and other factors like climate variability (temperature, rainfall, relative humidity, evapotranspiration) coupled with remote sensing and GIS data and techniques are further required. It is further suggested that a thorough and more detailed study must be taken up to examine the inter-linkages between wetland ecosystems and population growth 
and its associated activities at micro- and macro-levels. We hope this study will help the policymakers to gain some inputs for understanding the wetland ecosystem scenario of Kashmir Valley and the associated changing LULC patterns and framing policies for maintaining and improving ecological integrity of these aquatic ecosystems in a practical, eco-friendly, and sustainable manner.

Acknowledgement The authors acknowledge Indian Council of Social Science Research (ICSSR) for the financial assistance to carry out the current research work. Authors are also grateful to the anonymous reviewers for their valuable suggestions for improving the overall quality of the research work.

\section{Compliance with ethical standard}

Conflict of interest All the authors declare that the Authors have no conflict of interest for their entitled research paper "Assessing Land Use Land Cover Dynamics of Wetland Ecosystems using Landsat Satellite Data".

\section{References}

1. Ahmad F (2012) Detection of change in vegetation cover using multi-spectral and multi-temporal information for District Sargodha. Pakistan Soc Nat 24(3):557-571

2. Alam A, Bhat MS, Maheen M (2019) Using Landsat satellite data for assessing the land use and land cover change in Kashmir valley. GeoJournal 22:1-5

3. Alam A, Rashid SM, Bhat MS, Sheikh AH (2011) Impact of land use/land cover dynamics on Himalayan wetland ecosystem. J Exp Sci 2(3):60-64

4. Anderson JR (1976) A land use and land cover classification system for use with remote sensor data. US Government Printing Office, Washington, DC

5. Badar B, Romshoo SA (2007) Assessing the pollution load of Dal lake using geospatial tools. Forest 11(14754.858):4.

6. Bhuvaneswari K, Dhamotharan R, Radhakrishnan N (2011) Remote sensing satellite data for coastal ecosystem and human interaction: a case study in Tamil Nadu. India Int J Comput Inf Syst 2(4):77-81

7. Brown DG, Pijanowski BC, Duh JD (2000) Modeling the relationships between land use and land cover on private lands in the Upper Midwest, USA. J Environ Manag 59(4):247-263

8. Bui TD, Maier SW, Austin CM (2014) Land cover and land use change related to shrimp farming in coastal areas of Quang Ninh, Vietnam using remotely sensed data. Environ Earth Sci 72(2):441-455

9. Cohen J (1960) A coefficient of agreement for nominal scales. Edu Psychol Meas 20(1):37-46

10. Congalton RG (1991) A review of assessing the accuracy of classifications of remotely sensed data. Remote Sens Environ 37(1):35-46

11. Dimyati MU, Mizuno K, Kobayashi S, Kitamura T (1996) An analysis of land use/cover change in Indonesia. Int J Remote Sens 17(5):931-944

12. Donner $\mathrm{S}$ (2003) The impact of cropland cover on river nutrient levels in the Mississippi River Basin. Global Ecol Biogeogr 12(4):341-355

13. Dugan $P$ (1993) Wetlands in danger: a world conservation atlas. Oxford University Press, Oxford
14. Erener A, Düzgün S, Yalciner AC (2012) Evaluating land use/cover change with temporal satellite data and information systems. Proced Technol 1:385-389

15. Foley JA, DeFries R, Asner GP, Barford C, Bonan G, Carpenter SR, Chapin FS, Coe MT, Daily GC, Gibbs HK, Helkowski JH (2005) Global consequences of land use. Science 309(5734):570-574

16. Foody GM (2002) Status of land cover classification accuracy assessment. Remote Sens Environ 80(1):185-201

17. Funk DW, Pullman ER, Peterson KM, Crill PM, Billings WD (1994) Influence of water table on carbon dioxide, carbon monoxide, and methane fluxes from taiga bog microcosms. Global Biogeochem Cycles 8(3):271-278

18. Ganaie TA, Jamal S, Ahmad WS (2020) Changing land use/land cover patterns and growing human population in Wular catchment of Kashmir Valley, India. GeoJournal 29:1-8

19. Garg JK, Singh TS, Murthy TV (1998) Wetlands of India. Project report: RSAM. SAC/RESA/PR/01/98, 1998, Space Applications Centre (ISRO), Ahmedabad

20. Gillies RR, Box JB, Symanzik J, Rodemaker EJ (2003) Effects of urbanization on the aquatic fauna of the Line Creek watershed, Atlanta: a satellite perspective. Remote Sens Environ 86(3):411-422

21. Giri C, Ochieng E, Tieszen LL, Zhu Z, Singh A, Loveland T, Masek J, Duke N (2011) Status and distribution of mangrove forests of the world using earth observation satellite data. Global Ecol Biogeogr 20(1):154-159

22. Gorham E (1991) Northern peatlands: role in the carbon cycle and probable responses to climatic warming. Ecol Appl 1(2):182-195

23. Guo M, Li J, Sheng C, Xu J, Wu L (2017) A review of wetland remote sensing. Sensors 17(4):777

24. Herold M, Scepan J, Clarke KC (2002) The use of remote sensing and landscape metrics to describe structures and changes in urban land uses. Environ Plan A 34(8):1443-1458

25. Holden J (2005) Peatland hydrology and carbon release: why small-scale process matters. Philos Trans R Soc A Math Phys Eng Sci 363(1837):2891-2913

26. Iqbal MF, Khan IA (2014) Spatiotemporal land use land cover change analysis and erosion risk mapping of Azad Jammu and Kashmir, Pakistan. Egypt J Remote Sens Space Sci 17(2):209-229

27. Islam MS, Ahmed R (2011) Land use change prediction in Dhaka city using GIS aided Markov chain modeling. J Life Earth Sci 6:81-89

28. Jat MK, Garg PK, Khare D (2008) Modelling of urban growth using spatial analysis techniques: a case study of Ajmer city (India). Int J Remote Sens 29(2):543-567

29. Ji W, Ma J, Twibell RW, Underhill K (2006) Characterizing urban sprawl using multi-stage remote sensing images and landscape metrics. Comput Environ Urban Syst 30(6):861-879

30. Kachoosangi FT, Karbassi A, Sarang A, Noori R (2020) Sedimentation rate determination and heavy metal pollution assessment in Zariwar Lake. Iran SN Appl Sci 2(9):1

31. Kaul V, Handoo JK (1979) Water characteristics of some fresh water bodies of Kashmir. Curr Trends Life Sci 9:221-246

32. Khan MA (2008) Chemical environment and nutrient fluxes in a floodplain wetland ecosystem, Kashmir Himalayas. India Indian For 134(4):505-514

33. Kraiem HA (2002) Biophysical and socio-economic impacts of climate change on wetlands in the Mediterranean. Mediterr Roundtable

34. Lambin EF, Turner BL, Geist HJ, Agbola SB, Angelsen A, Bruce JW, Coomes OT, Dirzo R, Fischer G, Folke C, George P (2001) The causes of land-use and land-cover change: moving beyond the myths. Global Environ Change 11(4):261-269 
35. Lesschen JP, Verburg PH, Staal SJ (2005) Statistical methods for analysing the spatial dimension of changes in land use and farming systems. International Livestock Research Institute, Kenya

36. Li M, Zang S, Zhang B, Li S, Wu C (2014) A review of remote sensing image classification techniques: the role of spatio-contextual information. Eur J Remote Sens 47(1):389-411

37. Li SN, Wang GX, Deng W, Hu YM, Hu WW (2009) Influence of hydrology process on wetland landscape pattern: A case study in the Yellow River Delta. Ecol Eng 35(12):1719-1726

38. Liu T, Yang X (2015) Monitoring land changes in an urban area using satellite imagery, GIS and landscape metrics. Appl Geogr 56:42-54

39. Lone A, Babeesh C, Achyuthan H, Chandra R (2017) Evaluation of environmental status and geochemical assessment of sediments, Manasbal Lake, Kashmir. India Arabian J Geosci 10(4):92

40. Loveland TR, Acevedo W (2006) Land cover change in the Eastern United States Status and Trends in Eastern United States Land Cover Pretty J, Noble AD, Bossio D, Dixon J, Hine RE, Penning de Vries FWT, and Morison JIL Resource-conserving agriculture increases yields in developing countries. Environ Sci Technol 40(4):1114-1119

41. Lu D, Mausel P, Brondizio E, Moran E (2004) Change detection techniques. Int J Remote Sens 25(12):2365-2401

42. Lu D, Weng Q (2007) A survey of image classification methods and techniques for improving classification performance. Int J Remote Sens 28(5):823-870

43. Moser M, Prentice C, Frazier S (1996) A global overview of wetland loss and degradation

44. Mourya M, Kumari B, Tayyab M, Paarcha A, Rahman A (2020) Indices based assessment of built-up density and urban expansion of fast growing Surat city using multi-temporal Landsat data sets. GeoJournal 29:1-7

45. Ndzeidze SK (2008) Detecting changes in a wetland: using multispectral and temporal Landsat in the Upper Noun Valley Drainage Basin-Cameroon

46. Othman AA, Al-Saady Yl, Al-Khafaji AK, Gloaguen R (2014) Environmental change detection in the central part of Iraq using remote sensing data and GIS. Arabian J Geosci 7(3):1017-1028

47. Owojori A, Xie H (2005) Landsat image-based LULC changes of San Antonio, Texas using advanced atmospheric correction and object-oriented image analysis approaches. In: Proceedings of the 5th international symposium on remote sensing of urban areas, Tempe, AZ

48. Pandit AK, Qadri SS (1990) Floods threatening Kashmir wetlands. J Environ Manag 31(4):299-311

49. Papastergiadou ES, Retalis A, Kalliris P, Georgiadis T (2007) Land use changes and associated environmental impacts on the Mediterranean shallow Lake Stymfalia, Greece. Shallow Lakes in a changing world. Springer, Dordrecht, pp 361-372

50. Park NW, Chi KH, Kwon BD (2003) Geostatistical integration of spectral and spatial information for land-cover mapping using remote sensing data. Geosci J 7(4):335

51. Platt RV, Goetz AF (2004) A comparison of AVIRIS and Landsat for land use classification at the urban fringe. Photogramm Eng Remote Sens 70(7):813-819

52. Puyravaud JP (2003) Standardizing the calculation of the annual rate of deforestation. Forest Ecol Manag 177(1-3):593-596

53. Ramachandra TV, Sudarshan P, Vinay S, Asulabha KS, Varghese S (2020) Nutrient and heavy metal composition in select biotic and abiotic components of Varthur wetlands, Bangalore. India SN Appl Sci 2(8):1-4

54. Rani M, Kumar P, Yadav M, Hooda RS (2011) Wetland assessment and monitoring using image processing techniques: a case study of Ranchi. India J Geogr Inform Syst 3(4):345-350

55. Rappold AG, Stone SL, Cascio WE, Neas LM, Kilaru VJ, Carraway MS, Szykman JJ, Ising A, Cleve WE, Meredith JT, Vaughan-Batten $\mathrm{H}$ (2011) Peat bog wildfire smoke exposure in rural North Carolina

SN Applied Sciences is associated with cardiopulmonary emergency department visits assessed through syndromic surveillance. Environ Health Perspect 119(10):1415-1420

56. Rashid SA, Ganai JA, Masoodi A, Khan FA (2015) Major and trace element geochemistry of lake sediments, India: implications for weathering and climate control. Arabian J Geosci 8(8):5677-5684

57. Rogan J, Chen D (2004) Remote sensing technology for mapping and monitoring land-cover and land-use change. Prog Plan 61(4):301-325

58. Rosenfield GH, Fitzpatrick-Lins K (1986) A coefficient of agreement as a measure of thematic classification accuracy. Photogramm Eng Remote Sens 52(2):223-227

59. Schmidt KS, Skidmore AK (2003) Spectral discrimination of vegetation types in a coastal wetland. Remote Sens Environ 85(1):92-108

60. Seif A, Mokarram M (2012) Change detection of gil playa in the northeast of Fars province. Iran Am J Sci Res 86:122-130

61. Shah SA (2012) Use of geographic information system in land use studies: a micro level analysis. Eur J Appl Sci 4(3):123-128

62. Shooshtari SJ, Gholamalifard M (2015) Scenario-based land cover change modeling and its implications for landscape pattern analysis in the Neka Watershed. Iran Remote Sens Appl Soc Environ 1:1-9

63. Slater LD, Reeve A (2002) Investigating peatland stratigraphy and hydrogeology using integrated electrical geophysics. Geophysics 67(2):365-378

64. Taqi M, Bidhuri S, Sarkar S, Ahmad WS, Wangchok P (2017) Rural healthcare infrastructural disparities in India: a critical analysis of availability and accessibility.

65. Turner BL, Lambin EF, Reenberg A (2007) The emergence of land change science for global environmental change and sustainability. Proc Natl Acad Sci 104(52):20666-20671

66. Turner MG, Gardner RH, O'neill RV, O'Neill RV, (2001) Landscape ecology in theory and practice. Springer, New York

67. Van Der Werf GR, Randerson JT, Giglio L, Collatz GJ, Kasibhatla PS, Arellano Jr AF (2006) Interannual variability of global biomass burning emissions from 1997 to 2004.

68. Verburg PH, van Eck JR, de Nijs TC, Dijst MJ, Schot P (2004) Determinants of land-use change patterns in the Netherlands. Environ Plan B Plan Design 31(1):125-150

69. Wang L, Sousa WP, Gong P (2004) Integration of object-based and pixel-based classification for mapping mangroves with IKONOS imagery. Int J Remote Sens 25(24):5655-5668

70. Wondrade N, Dick ØB, Tveite H (2014) GIS based mapping of land cover changes utilizing multi-temporal remotely sensed image data in Lake Hawassa Watershed. Ethiopia Environ Monit Assess 186(3):1765-1780

71. Yang X, Liu Z (2005) Using satellite imagery and GIS for land-use and land-cover change mapping in an estuarine watershed. Int J Remote Sens 26(23):5275-5296

72. Yin ZY, Stewart DJ, Bullard S, MacLachlan JT (2005) Changes in urban built-up surface and population distribution patterns during 1986-1999: a case study of Cairo. Egypt Comput Environ Urban Syst 29(5):595-616

73. Zoran M, Anderson E (2006) The use of multi-temporal and multispectral satellite data for change detection analysis of the Romanian Black Sea coastal zone. J Optoelectron Adv Mater 8(1):252

74. Zubair AO (2006) Change detection in land use and Land cover using remote sensing data and GIS (A case study of llorin and its environs in Kwara State). University of Ibadan, Department of Geography

Publisher's Note Springer Nature remains neutral with regard to jurisdictional claims in published maps and institutional affiliations. 